\title{
Reflections of the İstanbul Hilton Hotel on Mid-century Hotel Buildings in Turkey*
}

\author{
Hande Atmaca Çetin ${ }^{* *} \odot$, Zeynep Tuna Ultav ${ }^{*+*} \oplus$, Funda Uz ${ }^{*+*+*} \odot$
}

\begin{abstract}
The 1950s indicate a period of America's influence on the world economy and culture with its post-war power. Mobility increased with developing transportation networks and emerging consumer culture, so the number and importance of hotels increased as a result of this socio-political, economic and architectural condition of the period. In the 1950s, American chain hotels emerged, and soon spread overseas, following the dominant aesthetics of the country, a version of the International Style termed as "American Modernism". The spread of International Style through modern hotels was most prominent in Hilton Hotels. The first modern hotel to arrive in Turkey was the İstanbul Hilton Hotel which influenced other hotel buildings in the 1950s to follow the International Style. The Hilton Hotel was frequently accepted as a model behind the tourism discussions and the initiatives that followed were compared with it, although the spread of its architectural language created a debate in architectural circles. For this reason, the focal point of this study is the hotel buildings designed in the International Style between 1950 and 1960, which possess architectural similarities with the Hilton Hotel. The influence of the Hilton Hotel on other hotel buildings in the 1950s is investigated along with the period's tourism discussions to have a wider perspective of the Hilton Hotel's influence on tourism. The hotels selected for the study are ones that carry the aesthetical principles of the Hilton Hotel, and were built or started construction in 1950s; Büyükada Anadolu Club Hotel, Çınar Hotel, Eskişehir Porsuk Hotel, Grand Efes Hotel, and Grand Tarabya Hotel. These examples illustrate the effects of the Hilton Hotel on the development of modern tourism architecture.
\end{abstract}

\section{Keywords}

Hilton Hotel • International style • Büyükada Anadolu Club Hotel • Çınar Hotel • Eskişehir Porsuk Hotel • Grand Efes Hotel - Grand Tarabya Hotel

\section{İstanbul Hilton Otel’in Türkiye'deki Yüzyıl Ortası Otel Binaları Üzerindeki Etkileri}

\section{Öz}

1950’li yıllar Amerika'nın savaş sonrası elde ettiği güç ile dünya ekonomisini ve kültürünü etkilediği yıllardır. Gelişen tüketim kültürü ve ulaşım ağları ile mobilite artmış, oteller dönemin sosyo-politik, ekonomik ve mimari durumunun bir sonucu

* This paper is an outcome of the ongoing doctoral dissertation "Reading the Modern through Hotel Interiors of the 1950s: Divan and Çınar Hotels in İstanbul” prepared by Hande Atmaca Çetin and supervised by Assoc. Prof. Funda Uz and Assoc. Prof. Zeynep Tuna Ultav in Architectural History Doctoral Program, İstanbul Technical University.

** Correspondence to: Hande Atmaca Çetin (Lecturer), İzmir University of Economics, Faculty of Fine Arts and Design, Department of Interior Architecture and Environmental Design, İzmir, Turkey. E-mail: hande.atmaca@ieu.edu.tr ORCID: 0000-0003-2664-0228

*** Zeynep Tuna Ultav (Assoc. Prof.), Yaşar University, Faculty of Architecture, Department of Interior Architecture and Environmental Design, İzmir, Turkey. E-mail: zeynep.tunaultav@yasar.edu.tr ORCID: 0000-0003-0478-7333

$* * * *$ Funda Uz (Assoc. Prof.), Istanbul Technical University, Faculty of Architecture, Department of Architecture, Istanbul, Turkey. E-mail: uzfunda@itu.edu.tr ORCID: 0000-0003-4299-7710

To cite this article: ATMACA CETIN, Hande; TUNA ULTAV, Zeynep; UZ, Funda, "Reflections of the İstanbul Hilton Hotel on Mid-century Hotel Buildings in Turkey", Art-Sanat, 12(July 2019), s. 57-88.

https://doi.org/10.26650/artsanat.2019.12.0016 
olarak çoğalmıştır. 1950'li yıllarda Amerika'da zincir oteller ortaya çıkarak deniz aşırı yayılmış ve mimari olarak Uluslararası Stil'in "Amerikan Modernizmi" olarak tanımlanan bir versiyonunu takip etmiştir. Uluslararası Stil'in modern oteller üzerinden yayılması en belirgin olarak Hilton Oteller ile olmuştur. Türkiye'ye ilk modern otel Hilton Otel ile gelmiş, böylece 1950'li yıllarda Hilton Oteli sonrasında yapılan birçok otel Uluslararası Stil'den etkilenmiştir. Turizm tartışmalarının arkasında Hilton Otel sıkça bir model olarak kabul edilmiş, mimarlıkta ise bu mimari dilin koşulsuz yayılması tartışmalara sebep olmuştur. Bu çalışmanın odak noktası 1950-1960 yılları arasında Uluslarası Stil'de yapılan ve İstanbul Hilton Oteli ile yapısal benzerlikler taşıyan Türkiye'deki otel binalarıdır. Hilton Oteli'nin 1950'lerde diğer otel binaları üzerindeki etkisi tartışılırken dönemin turizm tartş̧malarına da yer verilerek Hilton Oteli'nin Türkiye'deki etkisi daha geniş bir perspektifte aktarılmıştır. Çalışma amacıyla seçilen oteller Hilton Oteli ile en büyük yapısal benzerliği taşıyan oteller arasından, 1950'li yıllarda inşa edilmiş ya da inşaatına başlanmış olan Büyükada Anadolu Kulübü Oteli, Çınar Otel, Eskişehir Porsuk Oteli, Büyük Efes Oteli, Büyük Tarabya Oteli ile ele alınmış, bu oteller üzerinden Uluslararası Stil'in ve Hilton Otel'in Türkiye'de modern turizm mimarisi üzerindeki izleri sürülmüştür.

\section{Anahtar Kelimeler}

Hilton Otel • Uluslararası stil • Büyükada Anadolu Kulübü Oteli • Çınar Otel • Eskişehir Porsuk Oteli • Büyük Efes Oteli • Büyük Tarabya Oteli

\section{Genisletilmis Özet}

1950'li yıllar Amerika'nın savaş sonrası elde ettiği güç ile dünya ekonomisini ve kültürünü etkilediği yıllardır. Gelişen ulaşım ağları ile mobilite artmış, oteller dönemin sosyo-politik, ekonomik ve mimari durumunun bir sonucu olarak çoğalmıştır. 1950'li yıllar Amerika'da zincir otellerin ortaya çıtığı ve deniz aşırı taşındığı yıllardır. Mimarlık alanında ise Amerika'da dominat estetik 1950'lerde Uluslararas1 Stil'in Amerikan Modernizmi olarak adlandırılan bir versiyonunu takip eder ve Amerika'da modern zincir oteller bu kodlara uygun şekilde tasarlanmaya başlar. Hilton Oteller zinciri bu dönemin ekonomik, sosyo-politik ve mimari atmosferini yansıtan bir sonuç olarak doğar ve yayıldığı ülkelere Amerikan tarzı bir politikayı, yaşamı ve mimariyi sunarlar.

Türkiye'de ise 1950'ler tarihçiler açısıdan birçok kırılmanın yaşandığı yıllar olarak adlandırılır. İlk kez çok partili düzene geçilirken Demokrat Parti rejimi ile Türkiye yüzünü Amerika'ya döner. 1950'ler, Türkiye'nin kapılarını uluslararası bir düzene açtığı yıllardır. Marshall yardımları, Kore Savaşına katılım ve NATO'ya giriş ile yeni bir düzene girilir. Uluslararası alanda varolma çabaları içerisinde turizm büyük önem teşkil etmekte, turizmi desteklemek için yatırımların teşviği devletin en önemli gündemlerinden birini oluşturmaktadır.

İstanbul'da modern otellerin bulunmaması, 1950'li y1llarda gazetelerin makalelerine yansıyan genel bir eleştiridir. İstanbul Hilton Oteli'nin açılması Türkiye'de modern turizmin başlangıcı olarak kabul edilmektedir. Bu önermeden başlayarak, bu çalışma kapsamında İstanbul Hilton Oteli'nin Türkiye'de modern turizm ve turizm mimarlığı açısından olan etkileri paralel olarak tartışılmıştır. Turizm tartışmalarında Hilton Otel bir örnek teşkil ederken, mimari açıdan Hilton Otel'in diğer oteller üzerindeki etkisi, kopya/taklit tartışmalarını beraberinde getirmiştir. Hilton otelin gridal 
düzendeki cephe karakterinin ve ondan bağımsız olarak ona "karakter" katmak adına eklenen kabuk strüktürlerin kolaycılıkla ve yaratıcılıktan uzak olarak diğer binalarda tekrar edilmesi Şevki Vanlı tarafından 1958'de "Hiltonculuk" olarak eleştirilmiştir. Aynı tartı̧̧malar yapının yerel mimarı olan Sedad Hakkı Eldem tarafından da gündeme getirilmiş, Hilton Otel yüzyıl ortası Türkiye mimarlığında özgünlük tartışmalarının odağı haline gelmiştir. Bu çalışmanın odak noktası 1950-1960 yılları arasında Uluslararası Stil'de yapılan ve İstanbul Hilton Oteli ile yapısal benzerlikler taşıyan Türkiye'deki otel binalarıdır. Çalışma amacıyla seçilen oteller Hilton Oteli ile en belirgin yapısal benzerliği taşıyan oteller arasından, 1950'li yıllarda inşa edilmiş ya da inşaatına başlanmış olan Büyükada Anadolu Klübü Oteli, Çınar Otel, Eskişehir Porsuk Oteli, Büyük Efes Oteli, Büyük Tarabya Oteli ile ele alınmış, bu oteller üzerinden Uluslararası Stil'in ve Hilton Otel'in Türkiye'de modern turizm mimarisi üzerindeki izleri sürülmüştür. Aynı zamanda daha önce tartışmalara katılmamış olan, sadece haberlerde yer almış ya da proje aşamasında kalmış olup Hilton Otel ile benzerlikler taşıyan diğer projelere de yer verilerek bu etkinin ne derecede yayıldığııı göz önüne sermek amaçlanmıştır.

Turizm tartı̧̧maları içerisinde Hilton Otel sıkça bir model kabul edilmiş, sonrasındaki girişimler onunla karşılaştırılmıştır. Hilton Oteli daha sonra açılacak modern oteller için önayak olmuş, ona benzer otellerin yapılması turizm dergilerinde teşvik edilmiştir. Mimarlık alanında ise yaşanan en büyük tartışma, Hilton Otel'in gridal cephe düzeni, pilotiler üzerinde yükselen iki cephesi sağır dikdörtgen blok, transparan giriş kotundan oluşan mimari dilinin yayılması ve sonrasında gelen yapıların tartışmasız olarak standartlaşarak ona benzemesinden kaynaklanmaktadır. Hilton Otel'in tasarım kararlarının yarattığı estetik 1950'li yıllarda ilk olarak Şevki Vanlı'nın eleştirisini almıştır. Vanlı, Hilton'un dolaysız kopyasının sadece oteller değil sonraki konut ve hükümet binalarındaki uygulamalarına olan eleştirisini "Hiltonculuk" olarak adlandırmıştır. Vanlı, 1950'li yıllardaki binaların benzerliklerinin altını çizerek, balkonlu olup olmaksızın bu cephe dilinin yayıldığını ve otel odalarındaki modüler yapının bu işi daha uygulanabilir hale getirdiğini belirtmiştir. Bir süre sonra, cephedeki bu dil, rasyonel mimarinin temsili halini almıştır. Vanlı'nın "vasat yerli yapı tipolojisi" olarak nitelendirdiği bu dil, ona göre mimarların yeni bir anlayış aramaksızın yaratıcılıktan uzaklaşarak kolayca bu dili kabul etmelerinden kaynaklanmaktadır. Sonraki yıllarda SOM firması ile beraber otelin yerel danışmanlığını üstlenen Sedad Hakkı Eldem de bu tip binaların Anadolu'da koşulsuz yayılmasına olan eleştirisini dile getirmiştir.

Çalışmanın sonuçlarına göre incelenen binaların, Hilton Oteli'ni şekillendiren Uluslararası Stil'de tasarlandığı görülmektedir. Uluslararası Stil’i oluşturan kodlar olan; pilotiler üzerinde yükselen prizmatik blok, gridal cephe düzeni, camlı giriş katı, teras çatı kullanımı gibi unsurlar bu otellerde mevcuttur. Aynı zamanda Amerikan 
ve teras barlar, restoranlar, yüzme havuzlu geniş peyzajlı alanlar gibi farklı mekansal unsurlar da farklı seviyelerde otellerin programlarında bulunmaktadır. Çalışma kapsamındaki oteller Hilton Otel ile ana prensipleri paylaşmalarına rağmen, aralarındaki farklılıklar belirtilmelidir. Tarabya Oteli, arazi şekli nedeniyle eğrisel bir plastisite kazanmıştır. Anadolu Klübü binası, aynı dilde yerel bir yorumlamanın örneği olup geleneksel Türk evi ile ilgili unsurlar ve yerel alışkanlıklarla şekillenmiştir. Eskişehir Porsuk Otel, V sütunları tarafından taşınan yüksek hacim ile giriş bakımından farklılık göstermektedir. Büyük Efes Otel, hacimler üzerinde yarattığı çeşitlilik ile rasyonel tutumu kırmış aynı zamanda 1960'larda ortaya çıkmaya başlayan açısal formlarla çevreye uyum sağlayarak farklılaşmanın ilk işaretlerini göstermiştir.

Sonuç olarak, İstanbul Hilton Otel'in çalışma kapsamındaki otellerin mimari şekillenmesinde büyük etkisi görülmüştür. Bu anlamda yapılan kopya/taklit tartışmalarına karşı Hilton Otel'in yüzyıl ortası Türkiye'sinde bir öğrenme aracı olduğu düşünülmektedir. Bu anlamda yapılacak çıkarım Hilton Otel'in etkisinin Türkiye'de günün koşullarında dünyanın geri kalanına uyma tutkusu olarak görülebileceği yönündedir. Tanyeli, bir kavram olarak taklidin, gelişmekte olan coğrafyalarda olağan bir süreç olarak yaşanarak, orijinalin üretimini teşvik ettiğini ileri sürmektedir. Buradaki sorun, kopya ile orijinal arasındaki sınırların kesin olarak bölünmesidir; bu, özgünlüğün izlenmesini zorlaştırmaktadır, ancak daha yakın bir analiz çalışmanın özgünlüğünü ortaya koymaktadır. Bozdoğan ise "Hiltonculuk" olarak tabir edilen durumun taklitten öte, otel ve apartman gibi tekrara dayanan programlı binalar için rasyonel bir çözüm yolu olduğunu belirtmektedir. Bu sebeple, 1950'lerin mimari üretiminin, Türkiye'nin uluslararası bir yaklaşımı takip eden eğiliminin sonucu olarak ortaya çıktığı söylenebilir. Uz, mimarlığın önceki bilgileri genişletmeye dayandığını, bu nedenle mimarlıktaki "orijinal" ve "kopya" konusunun anlamsız olduğunu ifade etmektedir. Bu nedenle, son ürünü değil, sonucu oluşturan tüm süreçlere ve kavramlara bakmak gerektiğinin altını çizer. $\mathrm{Bu}$ anlamda tartışılan otel binaları, paralel olarak gelişen dünya anlayışının yansımasını gösteren örnekler olarak düşünülmelidir. 


\section{Introduction}

The purpose of this study is to investigate the effect of the İstanbul Hilton Hotel on the construction of modern tourism and tourism architecture in 1950's Turkey. Studying 1950s tourism architecture in relation to the Hilton Hotel is of crucial importance, since this time period provided the most significant examples influenced by this prominent example of International Style. The influence of the Hilton Hotel and International Style on architecture starting from the 1950s is widely touched upon in academic studies ${ }^{1}$ and hotels from this decade were largely compared with the Hilton example. However, its effect on tourism is rarely discussed, despite its key role in the development of modern tourism, via tourism architecture. The opening of the İstanbul Hilton Hotel is considered as marking the beginning of modern tourism in Turkey. As Gönlügür states, Hilton became a term synonymous with modern hotels. ${ }^{2}$ Starting from this point of view, the study discusses the Hotel's effect on the development of modern tourism and, in parallel, tourism architecture. The reason for the parallel discussion of these two issues is to underline that, rather than being shaped independently by the political, social or economic context in which they are formed, buildings are clearly shaped by these dynamics. On the other hand, the work puts forward more examples of hotel buildings which were planned but not built, to provide a larger area of discussion. For this reason, this study focuses on the topic with a wider perspective by evaluating both the Hilton Hotel's influence on tourism discussions and hotel buildings, to understand the complete background picture that gave way to tourism architecture of the period.

While discussing the topic from the two main perspectives of tourism and architecture, one further objective is to address the larger issue of originality, which was a key issue in architectural discourse regarding the Hilton Hotel and 1950s architecture in Turkey. According to Akcan and Bozdoğan, the effects of the Hilton Hotel on Turkish architecture were considered mostly pejorative. ${ }^{3}$ There was a widespread view that the Hilton Hotel's architectural language had disseminated regardless of function or context throughout the country, to the extent that the term "Hiltonism" (Hiltonculuk) was coined to describe this tendency by architect Şevki Vanlı. For this reason, the scope of the work covers Büyükada Anadolu Club, Çınar, Eskişehir Porsuk, Grand Efes and Grand Tarabya Hotels, which were constructed in the 1950s and show generally similar characteristics in the main formation of the building with the Hilton Hotel. Selected buildings reflect the architectural image of the Hilton Hotel with

1 These studies are elaborated on in detail under subtitle "The Influence of the Hilton Hotel on 1950s Tourism Architecture in Turkey".

2 Emre Gönlügür, American Architecture and the Promise of Modernization in Postwar Turkey, University of Toronto, Graduate Department of Art, Doctoral Dissertation, Toronto 2014.

3 Esra Akcan, Sibel Bozdoğan, Turkey: Modern Architectures in History, Glasgow 2013, pp. 104-137.

4 Şevki Vanlı, "Hiltonculuk”, Kim, 29 November 1958, pp. 31-32. 
a sculptural look, carrying the architectural principles as mentioned by Akcan and Bozdoğan, the honeycomb façade, rectangular prism raised on pilotis, and a transparent entrance block, topped with a roof terrace. ${ }^{5}$ The study includes Grand Tarabya and Çinar Hotels as hotels of the 1950s, since their construction process started in this period, although they were completed later. These buildings are important as examples of the biggest complexes, which were close to the standards of the Hilton Hotel, in terms of building formation and extensive land use. The main analysis of these five hotels include their stories, as well as their analyses of architectural features, and discuss how they were influenced by the Hilton Hotel and differed from it.

The study employs a qualitative method comprised of a literature review, observations, analysis of visuals obtained from a variety of archives, supported by personal interviews. The exploration of tourism related debates was focused on the period's tourism journals such as Turing magazine and Turizm Alemi as well as the newspapers of the period. Parallel to this, architecture journals such as Arkitekt, and popular lifestyle magazines such as Hayat were also examined. At the same time, an extensive library research was conducted to access tourism brochures from the 1950s. Other data related to these buildings was obtained from online databases, personal and hotels' archives. Another important selection of data was collected from face to face interviews conducted with people such as Mukadder Sezgin (Former Undersecretary of the Ministry of Culture and Tourism between 1950s-1980s), Kadri Kalaycioğlu (Architect of the Balin Hotel, one of the first modern hotels in the midcentury, 1953 Ankara), Gözen Küçükerman (Interior Architect worked in the 1960s and continues to do so) Esen Çetingil (Manager of the Çınar Hotel) and Emre Gönlügür (Architectural Historian, PhD).

\section{The İstanbul Hilton Hotel}

The construction of the İstanbul Hilton Hotel in Turkey was an event that affected political, social and architectural atmosphere. As Mukadder Sezgin, the former Undersecretary of Ministry of Culture and Tourism in the early 1960s states, "A single Hilton Hotel changed İstanbul, changed its lifestyle. A single Grand Efes Hotel changed İzmir". ${ }^{6}$ It was the first 5 -star hotel in Istanbul and Turkey, built as a result of the tourism development policy, according to the Prost Plan, on the " 2 nd Park" which is the detached green area running through Gezi Park. ${ }^{7}$ The İstanbul Hilton Hotel was designed by the American architectural firm Skidmore, Owings \& Merrill (SOM) with Sedad Hakk1 Eldem, the local architect from Turkey. ${ }^{8}$ The building was de-

5 E. Akcan, S. Bozdoğan, op. cit., p. 124.

6 Mukadder Sezgin, Personal Interview, Ankara 2018.

7 Sibel Conker, İstanbul'daki Kent Otellerinin Mekan Dizim Yöntemiyle Analizi, Yıldız Technical University, Graduate School of Natural and Applied Sciences, Unpublished Master's Thesis, İstanbul 2009, p.38.

8 Annabel Jane Wharton, Building the Cold War: Hilton International Hotels and Modern Architecture, U.S.A 2001, p.19. 
signed according to Hitchcock and Johnson's International Style ${ }^{9}$ principles (Fig.1). The architecture was guided by horizontal rectangular volumes, a reinforced concrete skeleton reflected on the façade, a structure that was sometimes built on pilotis and a transparent entry floor, and a roof terrace, which were reminiscent of Le Corbusier. ${ }^{10}$ The Hilton had placed the American suburb in the heart of İstanbul with impressive landscaped areas and swimming pools, supporting Conrad Hilton's comment that "Each of our hotels is a little America". ${ }^{11}$ The Hilton became a building determining the aesthetic standards of the period, which became a symbol of American influence on architecture, a representation of International Style "a la Amerika", an American version of modernization. ${ }^{12}$ The selection of the İstanbul for Hilton Hotel was guaranteed by the quality of the location provided by the state, a view of the Bosphorus from the top of the hill, an astonishing scenery to watch from hotels' rooms providing all American comfort. ${ }^{13}$

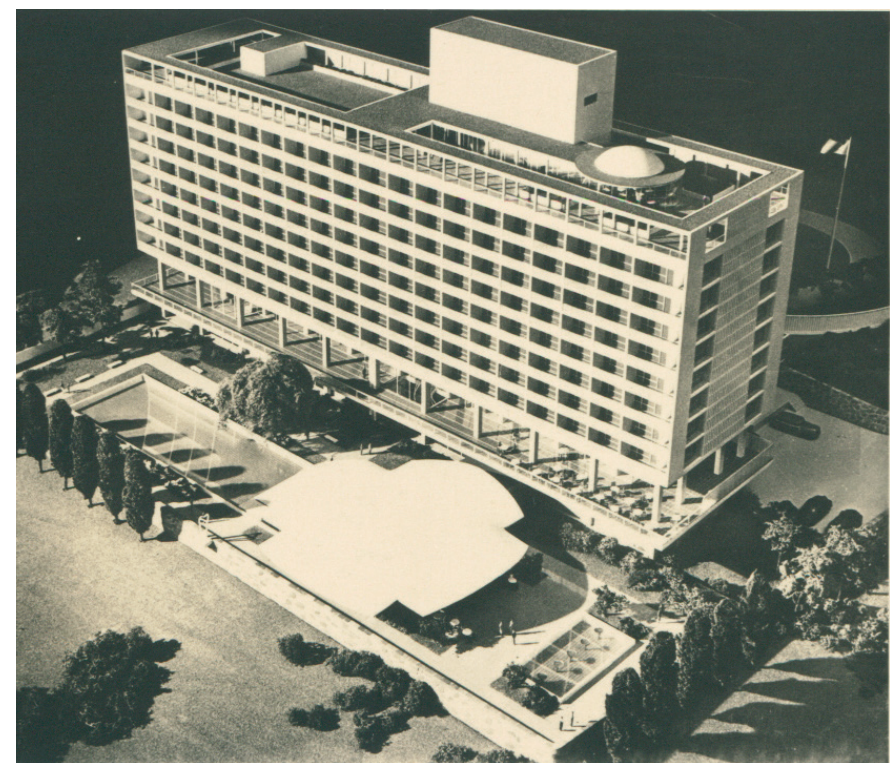

F.1. A postcard showing İstanbul Hilton Hotel's architectural model (İstanbul Atatürk Library Digital Archive, Krt_026571)

9 For further information please refer to, Henry Russell Hitchcock, Philip Johnson, The International Style: Architecture Since 1922, New York 1932.

10 Sibel Bozdoğan, "Turkey's Postwar Modernism: A Retrospective Overview of Architecture, Urbanism and Politics in the 1950s." Mid-Century Modernism in Turkey: Architecture across Cultures in the 1950s and 1960s, Ed. M. Gürel, New York and London 2016, pp. 9-26.

11 A. J. Wharton, Op. cit. p. 22.

12 Esra Akcan, "Americanization and Anxiety: Istanbul Hilton Hotel by SOM and Eldem", Oriental Occidental: Geography, Identity, Space. Ed. S. Bozdoğan, Ü. B. Copur, Paper presented at ACSA International Conference, 2001, p. 40.

13 Esra Akcan, “Amerikanlaşma ve Endişe: İstanbul Hilton Oteli”, Arredamento Mimarlık, İstanbul 2001, pp. 112-119. 


\section{İstanbul Hilton Hotel in Tourism Discussions}

In general, the lack of modern hotels in İstanbul was a general criticism dating back to newspaper articles of the 1940s with headlines such as "City Without a Hotel" 14 or "İstanbul's Hotel Issue". ${ }^{15}$ For Nayır, the existing hotels were converted mansions in the most congested places, in which, even for $1^{\text {st }}$ class hotels, hot water, service, cleaning was not available. Hotels did not have the modern qualities to be considered as "comfortable", "clean" or "peaceful" ${ }^{16}$ In tourism discussions the scenic and historical beauties of Istanbul were praised, but the city's organization problems, lack of hotels and communication with tourism agencies were regarded as the main issues. ${ }^{17}$ It should be noted here that, in mid-century İstanbul, the grand hotels of the $19^{\text {th }}$ century were still existent. As Gülersoy mentions, Pera Palas filled the need for a "palace" hotel similar to the examples seen in western countries. The hotel, which opened in 1895, combined the latest technology, with the comfort and luxurious mystique of an Eastern palace. ${ }^{18}$ Pera Palas existed during the glamourous 19 years before World War I. By the time of the Republic, the dominant role of the wealthy foreigner had been replaced by a calmer and more egalitarian approach to entertainment. However, by the 1950 s, the hotel could not compete with the newly-opened Hilton ${ }^{19}$, since $19^{\text {th }}$ century accommodation had lost its place in the search for new international standards of comfort. ${ }^{20}$ Apart from the architectural language, another way in which the Hilton differed from the grand hotels of the Ottoman or the Republican era exemplified by Pera Palas or Ankara Palas, was that, it provided amenities such as sports areas, a large lobby and soda fountains in the increasingly popular American style. ${ }^{21}$

Analyzing private sector development in Turkey in relation to the United States and Europe highlights the role of westernization, since Turkey was considered to be following western models. In the West, tourism was steered by the private sector, as opposed to countries such as Turkey, where state was involved in constructing extensive public works supporting the country's integration into the international arena. Even though the construction of tourism enterprises was not entirely in the hands of

14 Yaşar Nabi Nayır, "Otelsiz Şehir”, Yeni Sabah, 8 September 1941, Retrieved 28.05.2019 from Taha Toros Online Archive, http://earsiv.sehir.edu.tr:8080/xmlui/handle/11498/2422.

15 “İstanbul'un Otel Davas1", 1945, Retrieved 28.05.2019 from Taha Toros Online Archive, http://earsiv.sehir. edu.tr:8080/xmlui/handle/11498/2422.

16 Y. N. Nayır, op. cit., 1941.

17 Vahid Orgun, "Turizm ve Organizasyon”, Turizm Alemi, Vol. 2, April 1954.

18 Çelik Gülersoy, "Hotel d'Angleterre", Cumhuriyet, İstanbul 31 August 1989. Retrieved from Taha Toros Online Archive, http://earsiv.sehir.edu.tr:8080/xmlui/handle/11498/4234.

19 Divan Hotel was also mentioned here which fortified the decline of palace style hotels.

20 Vefa Zat, Eski İstanbul Otelleri: İstanbul Hilton 50 Yaşında, İstanbul 2005, p. 73.

21 Begüm Adalet, Hotels and Highways: The Construction of Modernization Theory in Cold War Turkey, California 2018, p. 162. 
the state, it provided a new turn to change tourism activities after the $1950 \mathrm{~s}^{22}$ For this reason, in 1950s, the promotion of investments in order to support tourism was one of the main agendas of the state, encouraged with the "Act for the Encouragement of Tourism" (Turizm Müesseselerini Teşvik Kanunu). Following this, in 1953, the Tourism Industry Encouragement Law No. 6086 (Turizm Endüstrisini Teşvik Kanunu) entered into force, exempting investors from taxation for 10 years. The Tourism Bank was founded in 1955 and in 1957 the Press-Publication and Tourism General Directorate became a ministry, under the title the Ministry of Press-Publication and Tourism. ${ }^{23}$ Between the years 1949 and 1957 the Press-Publication and Tourism General Directorate under the Prime Ministry significantly increased their tourism activities which had started during the first years of the Turkish Republic. Between 1957 and 1963 it became the Ministry of Press-Publication and Tourism (Basın-Yayın ve Turizm Bakanlığl $).{ }^{24}$ Most tourism investments in these years were facilitated by the state, by the development of The Pension Fund, The Tourism Bank, The Ministry of Press-Publication and Tourism. The Pension Fund (1949) was an institution that aimed to provide high standards of accommodation in cities through the expansion of trade and international tourism, also setting an example for foreign investments. The Pension Fund's investments led to prominent examples of hotels starting with the İstanbul Hilton Hotel (1955). ${ }^{25}$

The arrival of the İstanbul Hilton Hotel was announced early in Arkitekt journal in a 1952 article titled "Touristic Hotel" (Turistik Otel), featuring a detailed coverage of the building, and photographs of the upcoming building's model. ${ }^{26}$ In 1955, the opening was a grand celebration in the newpapers, as seen in the article "Finally the Hilton Hotel, or a hotel" (Nihayet Hilton Oteli veyahut bir otel). The Hilton Hotel was referred to as "The Hilton Palace" in the news, the first modern hotel in terms of architecture, works of art or luxuries, such as metres of woven carpets or elegant rooms. Two important merits were at hand: first, it could accommodate the most discerning guest, and second, it was a work of art that proved hotel buildings have a place in architecture. News reports concluded that, the hotel would be a source of pride for Istanbul, and it was hoped that the hotel would grow to 1000 rooms. $^{27}$

22 T. Elvan Altan, "Modern Tourism Architecture in 'A Country with Every Touristic Feature': An Overview of Hotels, Holiday Villages and Houses in Post-War Turkey", Enchanting Views: Romanian Black Sea Tourism Planning and Architecture of the 1960s and 70s, Ed. Alina Serban, Kalliopi Dimou, and Sorin Istudor, Bucharest 2015, pp. 236-249.

23 Zafer Yıldız, “Turizmin Sektörünün Gelişimi ve İstihdam Üzerindeki Etkisi”, Süleyman Demirel University, The Journal of Visionary, 3 (5), Isparta 2011, pp. 54-71.

24 Erol Evcin, "Basın-Yayın ve Turizm Bakanlığı Döneminde Turistik Tanıtım ve Propaganda (1957-1963)", Atatürk Dergisi, 6 (2), Erzurum 2016, pp. 41-91.

25 Zeynep Tuna Ultav, Gökçeçiçek Savaşır, 50 Yılın Ardından Türkiye'nin İlk Otel Motel Zinciri TUSAN, İzmir 2016, p. 34.

26 "Turistik Otel", Arkitekt, 1952-03, pp. 56-63.

27 "Finally the Hilton Hotel, or a Hotel", SALT Research, Rahmi M. Koç Archive, File No: D.156. 
After the opening of the Hilton Hotel, the public promotion of future similar hotels by the Pension Fund was inaugurated by the General Manager, Nuri Kınık, who announced "There will be 6 more hotels in the Hilton standard" (Hilton ayarinda 6 otel daha yapılacak). The article stated that "the anxieties of people over the construction phase, stating that these investments are dangerous for the Fund and only a dream for our country, should be at peace now". The article heralded the arrival of other hotels to be managed by foreign bodies. He continued that they signed the contracts with the state and started to launch the program after years of waiting, providing hotels in İstanbul, İzmir, Bursa, Antalya (cities full of natural beauty), to provide income to the country and the Pension Fund. These hotels, in the order of construction dates were; İzmir Hotel (German managed), Ankara Hotel (Swiss managed), $2^{\text {nd }}$ İzmir Hotel (American managed), and Florya Hotel (Austrian managed). ${ }^{28}$

The foreign press also praised the Hilton Hotel and advised the Pension Fund to build a similar hotel which could be read as a means of encouraging foreign investments. According to visiting French tourism experts, the country was on the verge of a breakthrough in tourism, but the biggest problem was the lack of trained personnel and the education needed in this regard. According to the article, tourism developments continued, and the newly opened Hilton Hotel would provide a great contribution to this, ${ }^{29}$ and to exceed the threshold, they advised a second hotel, similar to the Hilton Hotel, be built with French capital. ${ }^{30}$

The Hilton Hotel created a great impact in modern tourism architecture. This importance was evident, as seen from a tourism brochure from 1958, published by the Ministry of Press, Broadcasting and Tourism, citing the Hilton Hotel as a landmark, along with mosques and palaces (Fig.2). ${ }^{31}$ This effect was clearly evident in new hotel projects promoted in tourism and popular magazines, and discussions revolved around hotels comparing them to the Hilton. According to the article titled "New Hotels" (Yeni Oteller) published in Turing magazine in 1955, Istanbul continued to suffer from a hotel shortage after the opening of the Hilton Hotel, even while announcing the opening of four hotels (280 rooms to be built in Tarabya, the new Çınar Hotel to be built in Yeşilköy, the Tepebaşı Ambassador Hotel and a new hotel in the site of Taksim cinema), and mentioning the similarity of these new buildings to the Hilton Hotel. Each room would be en-suite, and at the same time, the rooms would be similar to those in the Hilton Hotel and could be used as a living room during the day. ${ }^{32}$ Another article illustrated the importance given to the Hilton Hotel, as the writ-

28 Aykut Görkey, "Hilton Ayarında 6 Otel Daha Yapılacak", Turing, December 1957, pp. 12-13.

29 It is also mentioned that two hotels similar to Divan, with modern equipment and a capacity of 100-120 beds would make a good contribution to tourism development.

30 Hüsnü Sadık Durukal, "Otelcilik Endüstrisi ve Turizm”, Turing, March 1956, pp. 3-4.

31 Ministry of Press, Broadcasting and Tourism, İstanbul [Brochure], İstanbul 1958, Turkey.

32 Enis Tahsin Til, "Yeni Oteller", Turing, September 1955, p. 15. 
er underlined that the country was attracting an increasing number of tourists, and this was due to the Hilton Hotel's worldwide name, clearing the doubts in tourists' minds about the lack of a hotel to stay in Turkey. ${ }^{33}$

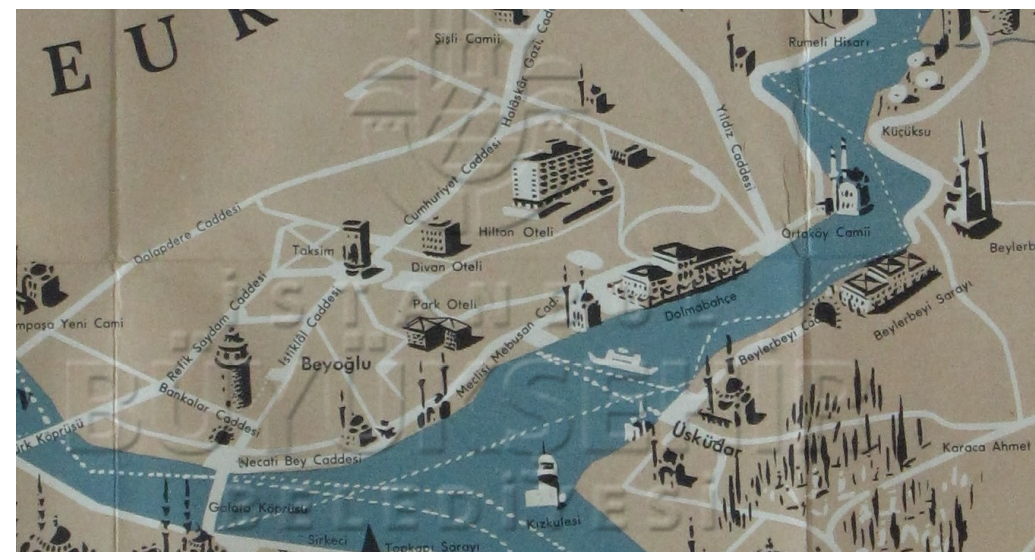

F.2. A tourism brochure's map showing the Hilton Hotel amongst the landmarks of Istanbul (Ministry of Press, Broadcasting and Tourism. İstanbul [Brochure]. 1958 İstanbul. Retrieved from Atatürk Library Digital Archive)

\section{The Influence of the İstanbul Hilton Hotel on 1950s Tourism Architecture in Turkey}

The influence of the Hilton Hotel was present in the implemented and as yet unimplemented hotel projects of the time. The biggest controversy in architecture stemmed from the standardization of buildings following the Hilton Hotel's architectural language, with no consideration of context or function. The aesthetic culture created by the Hilton Hotel's architectural language and the spread of the prismatic block with a grid façade was criticized by architect Şevki Vanl, who termed it "Hiltonculuk" (Hiltonism). Vanlı noted with disapproval that the scheme was subsequently employed by not only hotels but in housing and government buildings. He stated in 1958, "When we say Hiltonism, we think of buildings with a façade consisting of a series of balconies, as seen in Çınar Hotel or its children". He further stated that these are "easy" façades generated from the plan, and in order to provide character, it was necessary to add shell like structures or domes, unrelated to the overall design. ${ }^{34}$ This aesthetic Vanlı called "a mediocre typology of local architecture", highlighting that local architects accepted this rationale without creative efforts or interpretation. ${ }^{35} \mathrm{In}$ later years, even Sedad Hakk1 Eldem, the local architect of the Hilton Hotel with the

33 Ümit Atay, "Otel Davası Tamamen Halledilemiyor”, Turing, January 1956, p. 19.

34 Ş. Vanl1, "Hiltonculuk", op. cit., 1958.

35 Şevki Vanlı, Mimariden Konuşmak: Bilinmek İstenmeyen 20. Yüzyıl Türk Mimarlığı, Eleștirel Bakış (V1), Ankara 2006, p. 211. 
American architectural firm SOM, gave the following description "The silhouettes of building resembled a box, drawer, or radio. The buildings now have to be narrow with two blind sides and should sit on the pillars... Anatolian cities without defensive powers, after the cubic buildings, have been "invaded" by these pine and tin cans". ${ }^{36}$ As Adalet puts forward, Vanlı's criticism not only addressed the organization of the façade, but also on the "eccentric, flamboyant touches" as he described the concrete shell structures resembling cupolas, domes or pavilions. In Vanlı's assessments, these touches were added onto the International Style building as an after-thought to give it character. ${ }^{37}$

Asasoğlu states that the ease of construction of the modernist buildings also contributed to this paradigm. Modern architecture was spread via the rapid transfer of war technology, in order to revive civil architecture after World War II, since housing needs emerging in Europe needed a quick response. New technologies allowed easy and quick construction, and modern architecture was simple for the local building industry to comprehend. This is clearly illustrated by the tremendous difference between the workmanship of traditional wooden houses, which were built with traditional craftsmanship with accumulated knowledge over the years, and the ease of modern reinforced concrete constructions. This ease also brought with it the problem of "copying" that comes with modern architecture. ${ }^{38}$

Regarding the planned projects, discussions were also present in the popular magazines of time. Hayat magazine published a photograph of the model of another planned hotel project in Fenerbahçe (Fig.3), with a very similar design language to the Hilton Hotel. The organization of the honeycomb façade, rectangular elevated main block with a roof top, and the transparent entrance were visible in the architectural language, albeit with minor alternations. It was stated that the hotel would be run by a local firm, which was in contact with firms and architects in Hungary. The 180-room hotel would be very luxurious and the furnishings and mechanical infrastructure would be imported from Hungary. ${ }^{39}$

36 Sedad Hakkı Eldem, "Elli Yıllık Cumhuriyet Mimarlığı”, Mimarlık, Ankara 1973, p. 7.

37 B. Adalet, op. cit., 2018.

38 Ali Asasoğlu, Çağdaş Türk Mimarlığı Kimlik Arayışı Sürecinde Eklektik Eğilimler, Karadeniz Technical University, Institute of Natural Sciences, Master's Thesis, Trabzon 1988, pp. 7-8.

39 “Fenerbahçe’de Yapılacak Olan Otel”, Hayat, İstanbul 1 March 1957. 


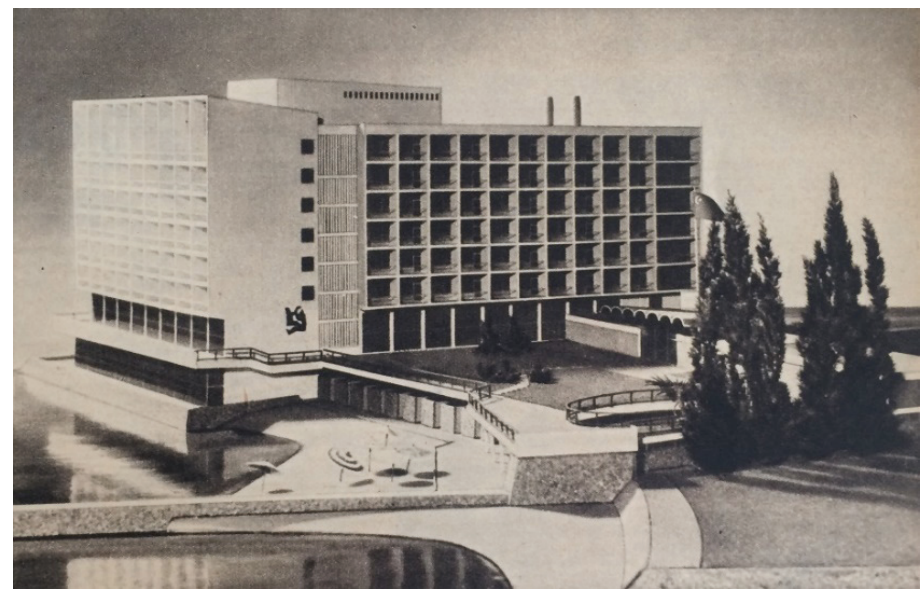

F.3. A newspiece advertising a hotel planned to be built in Fenerbahçe, with a similar formation to the Hilton Hotel (“Fenerbahçe'de yapılacak olan otel”, Hayat, İstanbul 1 March 1957.)

Another newspiece in Milliyet, 1957 announced another hotel project planned on the site of the burned down Denizpark Hotel in Yeşilköy (Fig.4). According to the report, the construction would be completed inside $3200 \mathrm{~m}^{2}$ land. The hotel would accommodate 17 floors (14 for the hotel's 322 rooms), overlooking the sea, and a number of facilities such as restaurants, and casinos. ${ }^{40}$

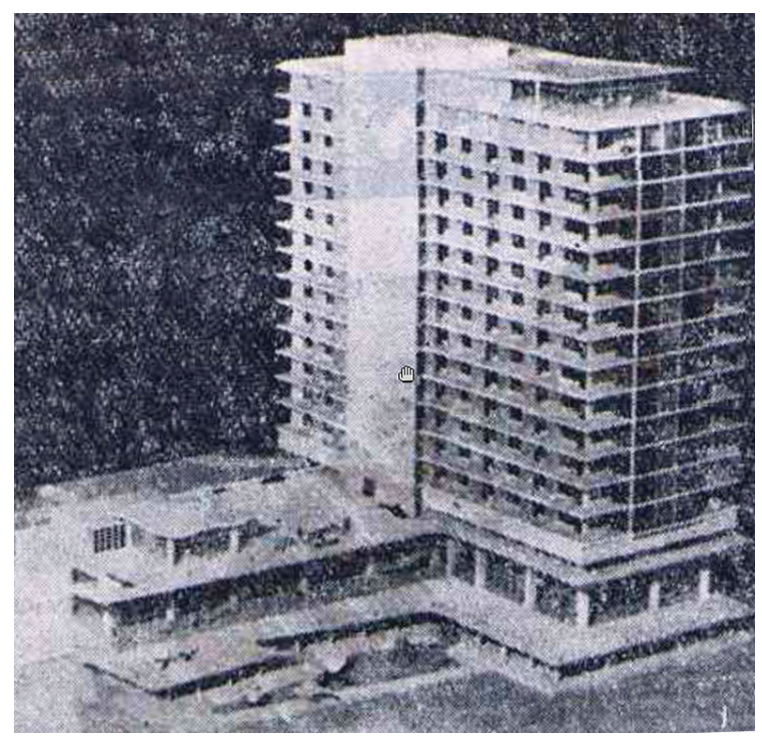

F. 4. A new hotel on the site of the burned down Denizpark Hotel (Özdemir Gürsoy, "17 Katl1 Otel”, Milliyet, 5 July 1958, Retrieved from http://gazetearsivi.milliyet.com.tr.)

40 Özdemir Gürsoy, “17 Katlı Otel”, Milliyet, 5 July 1958, Retrieved 28.05.2019 from http://gazetearsivi. milliyet.com.tr. 
In addition to architectural and popular publications, information about this architectural language was found in the works of local architects that were planned but never built. One hotel building that remained in the design stage, was the work of Rüknettin Güney. Kalamış Hotel (Fig. 5), planned by Güney in 1959 and never built due to financial problems, gives an idea of the influence of the Hilton Hotel. Similarly, another unimplemented hotel project, designed by Fazıl Aysu for Florya Beach Facilities, was created by bending the rectangular prism, sharing the design language of the Hilton Hotel (Fig. 6).

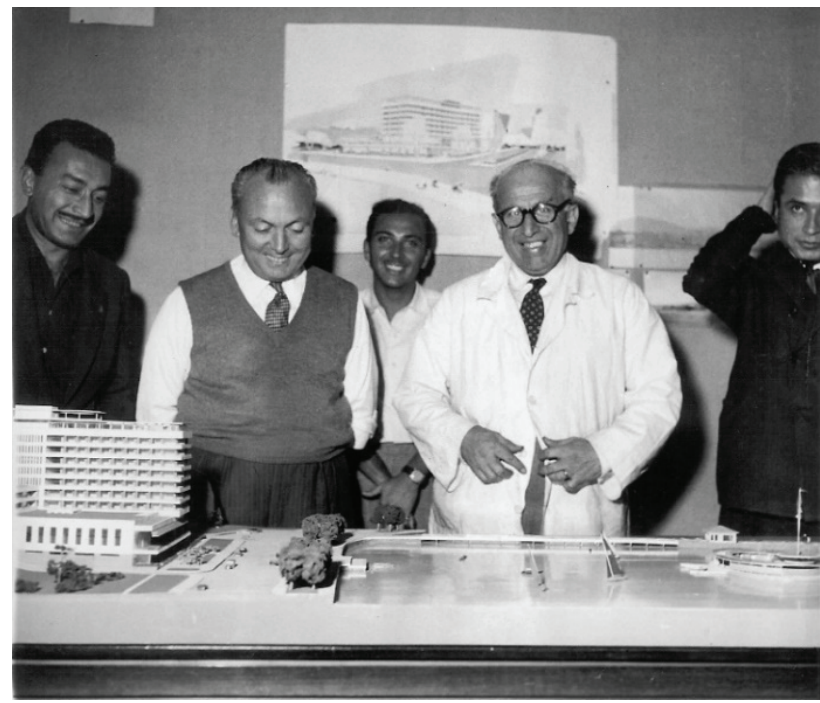

F. 5. Kalamış Hotel project's model, photograph taken inside the architectural office of Rüknettin Güney, late 1950s (Ahmet Güney Archive)

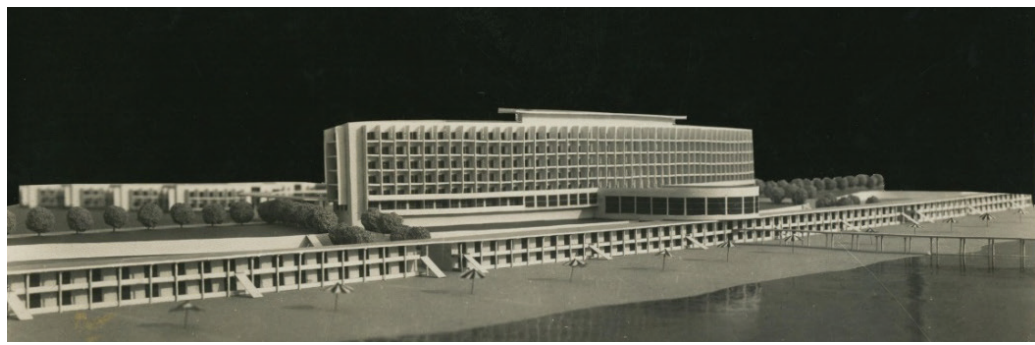

F. 6. Model of Florya Beach Project (SALT Research, Fazıl Saffet Aysu Archive)

Regarding the implemented projects, it could be stated that after the construction of the Hilton Hotel, its style spread extensively, becoming a common language in modern hotel architecture in Turkey. The basic prismatic main block, a grid system formed of reinforced concrete with balconies on the façade was reproduced several 
times with minor alterations. There was a large reception area, and bars and restaurants were placed on the ground floor, or in a more visible location - sometimes as an additional block with a distinctive roof, - and the hotel roof was a roof bar or a nightclub. These significant characteristics were clearly seen later on with the Çinar Hotel, which was situated on the Marmara shores, on an important newly opened axes between the airport and the city. Other examples were Eskişehir Porsuk Hotel and The Grand Efes Hotel in İzmir. A significant alteration of the grid block was the curved Grand Tarabya Hotel, on the edge of the Bosphorus, designed by Kadri Eroğan which started construction in $1957 .{ }^{41}$

These 1950s hotels under the influence of the Hilton could be categorized into two distinct tracks. The majority were constructed by the Pension Fund and the contractor firm Dyckerhoff and Windmann, which was in charge of building the Hilton Hotel. After the Hilton Hotel, the fund needed its own construction company; Emek Construction resulted from the Fund's cooperation with Dyckerhoff and Windmann, and would later build the Grand Efes and Grand Tarabya hotels. Eskişehir Porsuk Hotel was also constructed by a competition opened by the Pension Fund. The second category was private initiations, such as the Çınar Hotel and the Büyükada Anadolu Club Hotel. The interesting point here is that the construction of the Çinar Hotel was also conducted by Dyckerhoff and Windmann, indicating their influence both on the private sector and the state's efforts.

A closer look at the these five hotels would be beneficial to understand the socio-economical and architectural atmosphere they were designed and built in. The aforementioned hotels will be examined in the order of their opening dates to the public. (Table.1)

\begin{tabular}{|l|l|l|l|l|}
\hline Name of the Hotel & Architects & $\begin{array}{l}\text { Construction } \\
\text { Work }\end{array}$ & $\begin{array}{l}\text { Construction } \\
\text { Period }\end{array}$ & $\begin{array}{l}\text { Opening } \\
\text { Date }\end{array}$ \\
\hline İstanbul Hilton Hotel & $\begin{array}{l}\text { SOM, Sedad Hakk1 } \\
\text { Eldem }\end{array}$ & Emek Co. & $1952-1955$ & 1955 \\
\hline $\begin{array}{l}\text { Büyükada Anadolu } \\
\text { Club Hotel }\end{array}$ & $\begin{array}{l}\text { Abdurrahman Hanc1, } \\
\text { Turgut Cansever }\end{array}$ & Rad & $1953-1957$ & 1957 \\
\hline Çınar Hotel & $\begin{array}{l}\text { Rana Zıç1, Ahmet } \\
\text { Akın, Emin Ertam }\end{array}$ & $\begin{array}{l}\text { Dyckerhoff and } \\
\text { Windmann }\end{array}$ & $1954-1958$ & 1958 \\
\hline Eskişehir Porsuk Hotel & Vedat Dalokay & $\begin{array}{l}\text { A German } \\
\text { company }\end{array}$ & $1955-1957$ & 1959 \\
\hline Grand Efes Hotel & $\begin{array}{l}\text { Paul Bonatz, Fatin } \\
\text { Uran }\end{array}$ & Emek Co. & $1957-1963$ & 1965 \\
\hline Grand Tarabya Hotel & Kadri Eroğan & Emek Co. & $1958-1965$ & 1966 \\
\hline
\end{tabular}

Table 1. The chronology of 1950s hotels carrying the influence of the İstanbul Hilton Hotel. (The table was prepared by the authors with data provided by the sources cited in the article.)

41 E. Akcan, S. Bozdoğan, op.cit., p. 122. 


\section{Büyükada Anadolu Club Hotel}

A project similar to the Hilton Hotel won the national competition by architects Turgut Cansever and Abdurrahman Hanc1. ${ }^{42}$ According to Arkitekt journal, Büyükada Anadolu Club Hotel was started in 1953, and opened in 1957. Above a basement and a ground floor were 3 storeys with 57 apartment rooms. Each floor had an office and a lounge, with a bar on the terrace floor. The south facing corridor was shaded by sun breakers. A white volume with a modernist approach, it was considered to contribute to the island's scenic beauty. ${ }^{43}$

According to Kortan, it was built in accordance with the Rational-International understanding and the effects of Le Corbusier, with clear parallels to the Swiss Dormitory Building located in Paris. With the same purist principle, the staircase and the elevator formed their own masses, which were connected to the main block by a distinct volume. Unlike the Corbusier effect, pilotis did not leave the ground floor empty and a multipurpose space was created for the use of the hotel. The white color of the building was a deliberate contrast with the environment, in accordance with the Rational-International style. Plastic concrete experiments were also in line with the architecture of Le Corbusier. The building was considered a prime example of the period, with calm horizontal lines and proportional language in the façade and dimensions of the masses. ${ }^{44}$ As cited in Özorhon, Cansever pointed out the unique aspects of the building, stating that the most distinctive innovation was on the ground floor. In order to ensure the flow of land in the style of Le Corbusier, the building was carried on pilotis and the lower part was left empty. Cansever criticized not using this section since this garden area reflected a feature common in Turkish houses, which adjoined and overlooked the garden called "hayat" (life). For this reason, this type of variation was developed in the hotel building, with a seating area facing the sea. ${ }^{45}$

Vanlı regards this building as an example of a successful rationalist architecture, one of the finest examples of Turkish modernism. ${ }^{46}$ Kaçel also debates that every building created in the 1950s cannot be judged in the category of "Hiltonism". She states that inside the widely accepted and produced "common sense" architecture, there were examples of a "good sense", that was aware of its position inside the international language, but still in detail and understanding added a personal touch. ${ }^{47}$

42 E. Akcan, S. Bozdoğan, op. cit., p. 122.

43 “Anadolu Kulübü Binası”, Arkitekt, Vol. 295, 1959, p. 45-52.

44 Enis Kortan, Türkiye'de Mimarlık Hareketleri ve Eleștirisi, 1950-1960: XX. Yüzyılın Başından 1950'ye Kadar Olan Sürede Modern Mimarlığın Dünya'daki ve Türkiye'deki Gelişmesiyle Birlikte, Ankara 1971, p. 60.

45 Turgut Cansever, Personal Interview, 2006 as cited in İlker Fatih Özorhon, The Issue of Originality in Architecture: Turkish Modernity in the Period of 1950-60, İstanbul Technical University, Graduate School of Science, Engineering and Technology, Doctoral Dissertation, İstanbul 2008, p. 82.

46 Ş. Vanlı, Mimariden Konuşmak, op.cit., p. 230.

47 Ela Kaçel, "This is Not an American House: Good Sense Modernism in 1950s Turkey”, Ed. Duanfang Lu 
The unique character of the hotel was also reflected in the façade. Bozdoğan asserts that, while the horizontal form with balconies on the seaside façade resembles the Hilton, the other façade has a different pattern, with wooden lattice sunscreens allowing a soft light into the corridor. Attached there is a vertical block of circulation ending with a Corbusian parasol. The sunscreens also give reference to traditional Turkish houses and Masharabiya in Islamic architecture. Büyükada Anadolu Club Hotel is an example reflecting Turkish architects' capability of interpreting international aestetic standards. Hanc1, known as a follower of Corbusier, spent years in Paris, where he met Cansever, and implied cultural traces in a building that can not be categorized simply as "Corbusian, Tropical Modernist, Hiltonist or Islamic."

\section{The Çınar Hotel}

The Çınar Hotel was the first to show the evident influence of the Hilton Hotel, although this time with an investment of local capital. As Sayar Başaran states, on the site of the present hotel, there was initially the first Çınar Hotel, a small 15 room facility owned by Haydar Çınar in the early 1950s. Later, businessman Tevfik Ercan (1919-2004) and his brothers bought the hotel and land, demolished it to make way for the new Çınar Hotel. Sayar Başaran stated the hotel was "second only to the Hilton in popularity". ${ }^{49}$ Çetingil states that it was the one and only airport hotel in Turkey. ${ }^{50}$ Designed by the architects, Rana Zıpçı, Ahmet Akın, and Emin Ertam, the Çinar Hotel responded to the need for hotels in İstanbul (Fig. 7 and Fig. 8). ${ }^{51} \mathrm{~A}$ newspaper advertisement in $1958^{52}$ specifically emphasized that it was totally funded by Turkish capital and labour, stating its importance in the increasing local tourism investments in the country (Fig. 9).

Third World Modernism: Architecture, Development and Identity, London 2011, p. 165-185.

48 E. Akcan, S. Bozdoğan, op. cit., p. 124.

49 Sevgi Sayar Başaran, "Çınar Hotels Targets the Young”, Milliyet, İstanbul 9 March 2007.

50 Esen Çetingil, Personal Interview, İstanbul 2018.

51 “Çınar Oteli”, Arkitekt, Vol. 297, April 1959, pp. 132-140.

52 Rüçhan Ünver, "Haftaya Açılıyor”, Milliyet, 07 July 1958, p. 3. 


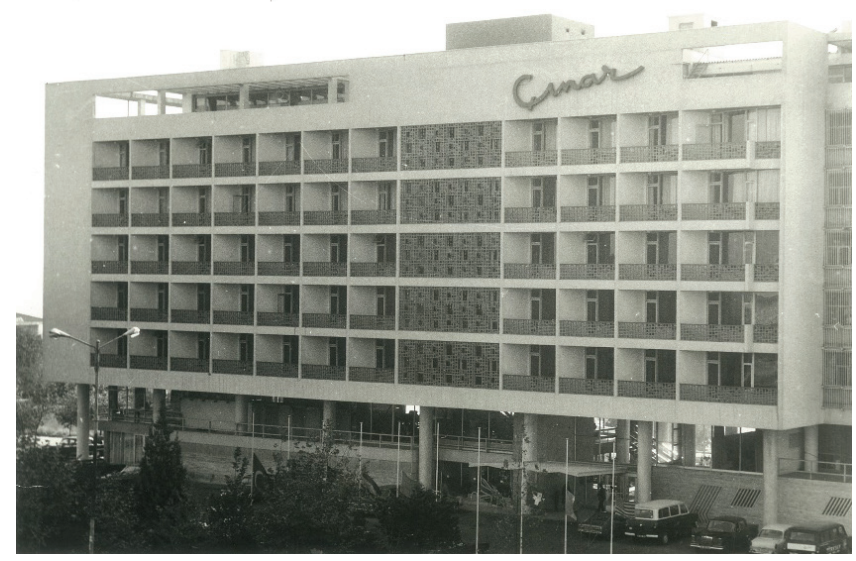

F. 7. A view of Çınar Hotel from the main entrance, from its early years (Çınar Hotel and Tuna Ultav Archives)

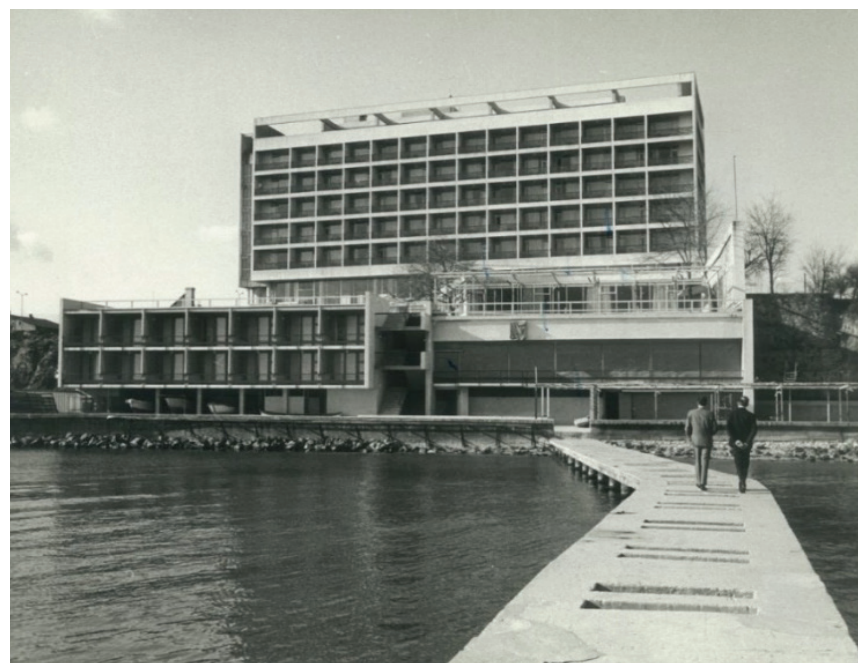

F. 8. A view of Çınar Hotel from the sea side, from its early years (Çınar Hotel and Tuna Ultav Archives) 


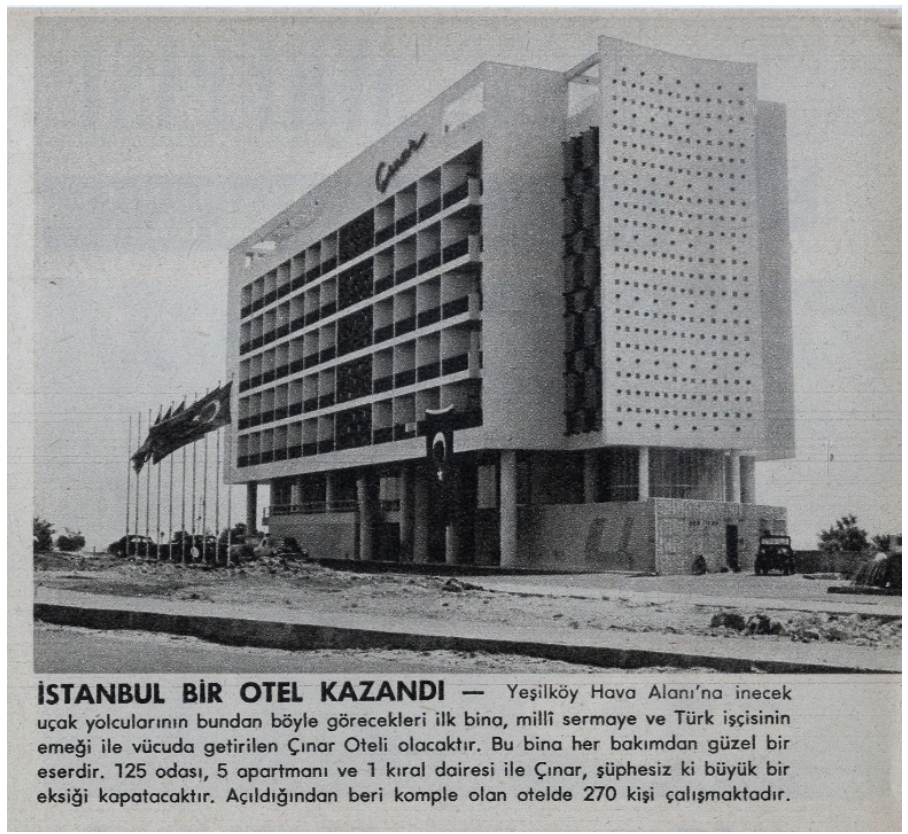

F. 9. News about the Çınar Hotel's opening (“İstanbul bir otel kazandı”, Hayat, 29 August 1958)

As stated in the project brief, the initial project was made up of one main block, and the beach facilities. On the ground floor, there was the reception, the bazaar and Bade Bar, while the mezzanine was reserved for resting, refreshments and ceremonies. The basement floor on the same level with the garden, accommodated recreation and service areas, such as restaurants, a pavilion, casino, a kitchen and laundry. ${ }^{53}$

As Gönlügür states, the Çınar Hotel was often compared to the Hilton Hotel in terms of the building's character. The main mass of bedrooms, the service volumes attached, the grid layout of each room reflected on the façade, the glass clad lobby and lounge areas on the entrance floor, were all seen as an implementation of the Hilton's building character. Thus, the Çınar Hotel was called the "Small Hilton" (Fig. 10). ${ }^{54}$ The resemblance was so close that Gönlügür highlights that the building on the cover of Hayat magazine in 1959, referenced by Kaçel ${ }^{55}$ as the "İstanbul Hilton", was actually the Çınar Hotel. This confusion underlines the level of similarity in the distinct architectural qualities recognizable even from a small portion of a photograph. ${ }^{56}$ (Fig. 11).

53 “Çınar Otel”, op. cit., 1959.

54 E. Gönlügür, op. cit., 2014, p.73.

55 Ela Kaçel, "Hiltonculuk and Beyond: The Dialectics of Intellectualism in Postwar Turkey", Candide: Journal for Architectural Knowledge, N. 3, Aachen 2010, pp. 9-35.

56 Emre Gönlügür, Personal Interview, İzmir 2019. 
The hotel mainly followed the principles of Hilton aesthetics and the International Style. The main block with its honeycomb façade was raised off the ground on pilotis. The main entrance was a separate transparent double-height volume, which was connected to the mezzanine level with a grand staircase. The independent plan, and the use of the roof garden were employed in the hotel design. The guestrooms opened towards the view, with their own bathroom and balconies. As pointed out by Küçükerman, there was a bazaar downstairs, just like in the Hilton Hotel which sold various Paşabahçe products in the stores and local Anatolian products for foreign customers. ${ }^{57}$

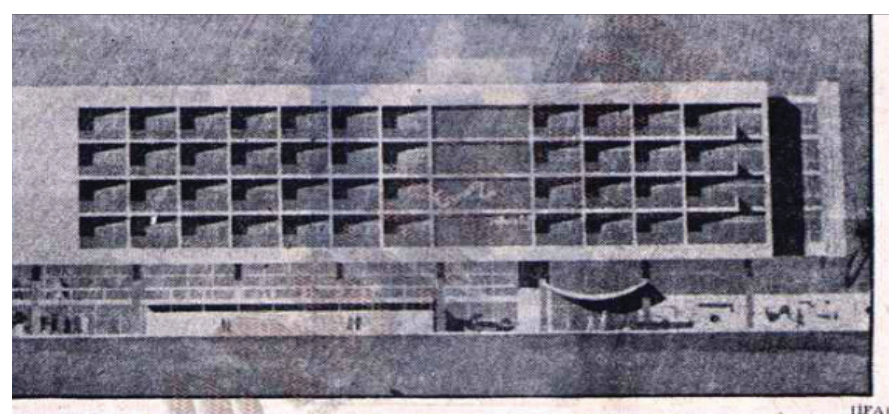

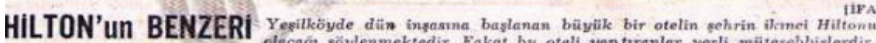
tel 130 odah, 6 kath olacak oe magat bir yl icinde tamamlatiacakfur. Hava meydenuna yakin bir yerde aptırimakta olan otelin Istanbula turist celbinderof onmayacağs ümit edilmektedir.

F.10. A newspiece about the Çınar Hotel titled as "A similar one to Hilton" ("Hilton'un Benzeri", Milliyet, 11 June 1955, Retrieved 28.05.2019 from http://gazetearsivi.milliyet.com.tr)

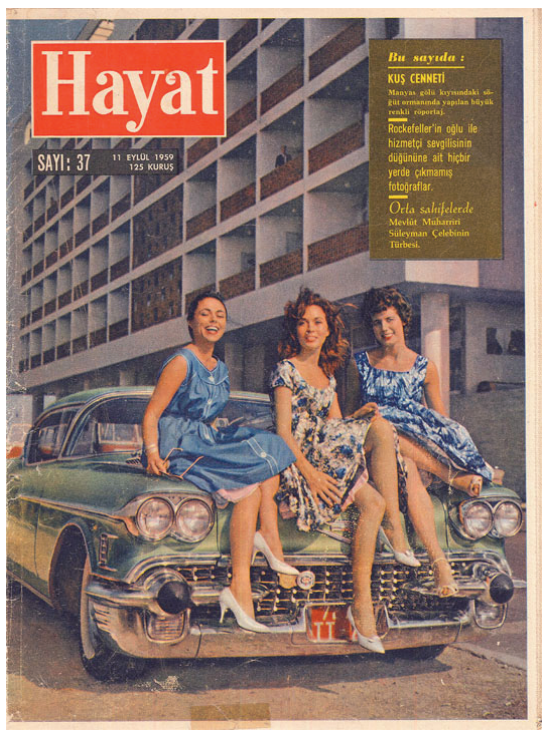

F.11. Cover of Hayat magazine in 1959, cited as "Hilton Hotel" by Kaçel instead of Çınar Hotel, due to their similarity of the architectural language (Hayat, 37, 11 September 1959)

57 Gözen Küçükerman, Personal Interview, İstanbul 2018. 
Kortan cites the Çınar Hotel as another example of Rational-International Architecture. The main block of the hotel was similar to the Hilton Hotel and did not display regional or specific features. It consisted of a raised rectangular prism on pilotis like the Hilton, in the same way, the larger rooms were placed at the two ends of the mass, changing the axis of the grid. The roof terrace was likewise considered as the Hilton Hotel. However, in the Çınar Hotel, the purism principle was broken with the service staircase placed at the end of the façade. Ceramic terracotta was used for the balustrade railings, in contrast to the teakwood balustrades at the Hilton. ${ }^{58}$

\section{Eskişehir Porsuk Hotel}

After World War II, the building sector began to grow after a period of stagnation and Eskişehir's urban texture changed due to migration and new roads. In the 1950s, new typologies emerged in Eskişehir, such as business centers, hotels, cinemas and hospitals through the efforts of the state and the private sector. ${ }^{59}$

The Hilton Hotel linguistically influenced other hotels - the Eskişehir Porsuk Hotel, a Pension Fund investment was also referred to as "Small Hilton". ${ }^{60}$ (Fig. 12) As stated in a newspiece in Milliyet, the hotel opened to the public in 27.10.1959. ${ }^{61}$ Eskişehir Porsuk Hotel was located on one of the busiest streets, on the banks of the Porsuk River. ${ }^{62}$ The building designed by architect Vedat Dalokay was the winner of a competition by the Pension Fund in 1955. It was finished in 1958, and in 1961, it was bought by the Ministry of Defence for use as an Officer's Club. The reinforced concrete building consisted of seven floors and a ground floor, and was built by a German company. The language of the building followed the principles of International Style and modern architecture, similar to the Hilton Hotel. The rectangular block with a honeycomb façade, the use of the terrace roof, was also seen in this building. At the top of the entrance, the domed glass mass carried by the $\mathrm{V}$ shaped columns created an entrance eave, while the office entrance was from the other side. ${ }^{63}$ As a variation of the Hilton model, the entrance was shaped rather differently. As Demirel Etli and Kurt state, the V-shaped columns at the bottom are thought to be the architect's signature feature (Fig.13). ${ }^{64}$

58 E. Kortan, op.cit., 1971, p.66.

59 Güler Koca, Rana Karasözen, “1945-1960 Dönemi Eskişehir Modern Kent Merkezinin Oluşumunda Öne Çıkan Yapılar”, Anadolu University Journal of Social Sciences, 10 (3), Eskişehir 2010, pp.191-211.

60 Gönlügür, op.cit., 2014, p.73.

61 "Eskişehir Porsuk Oteli Açılıyor", Milliyet, 21 October 1959.

62 Pınar Demirel Etli, Özlem Kurt, "Eskişehir Porsuk Oteli”, Docomomo_Türkiye Mimarlığında Modernizmin Yerel Açılımları, 31 October-2 December 2014 Erzurum.

63 G. Koca and R. Karasözen, ibid, 2010, p.199.

64 P. Demirel Etli and Ö. Kurt, ibid, 2014. 


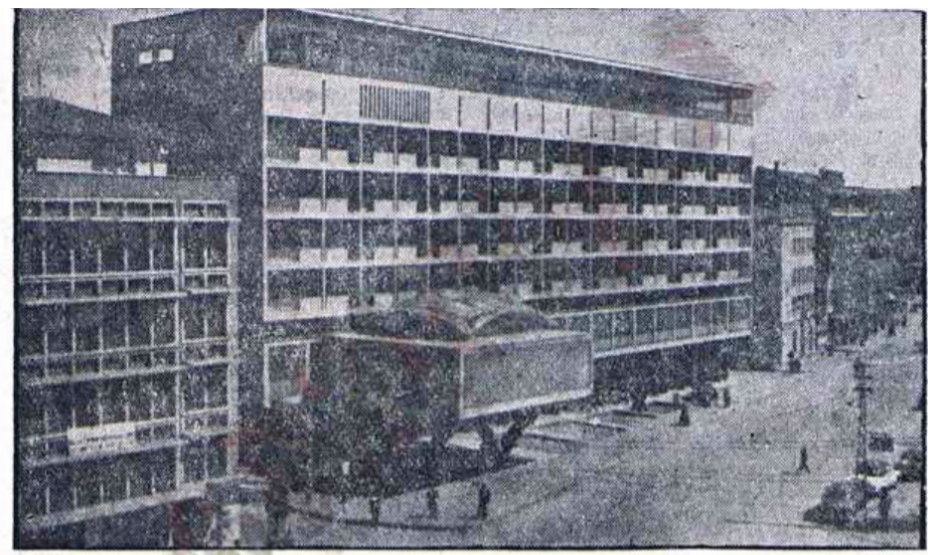

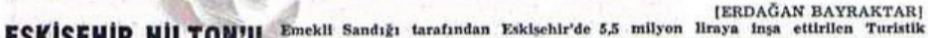
Porsuk Otell faallyete geçmiştir. Uzun zaman kiralanmayan otell EmekII Sandıs̆ Idare etmektedir. Otelde 36 tek, 52 cift yatakl, oda meveuttur. Otelde, gazino, lokanta, bar ve pastahaneler bulun-
maktadir. Belediye ráyiel disinda flat tesbit edilen otelin odalarinin tek ve sift yataklilarinin gecellgi $18-20$ liradir.

F.12. Porsuk Hotel cited in the newspaper as the Hilton of Eskişehir (Bayraktar, 1959)

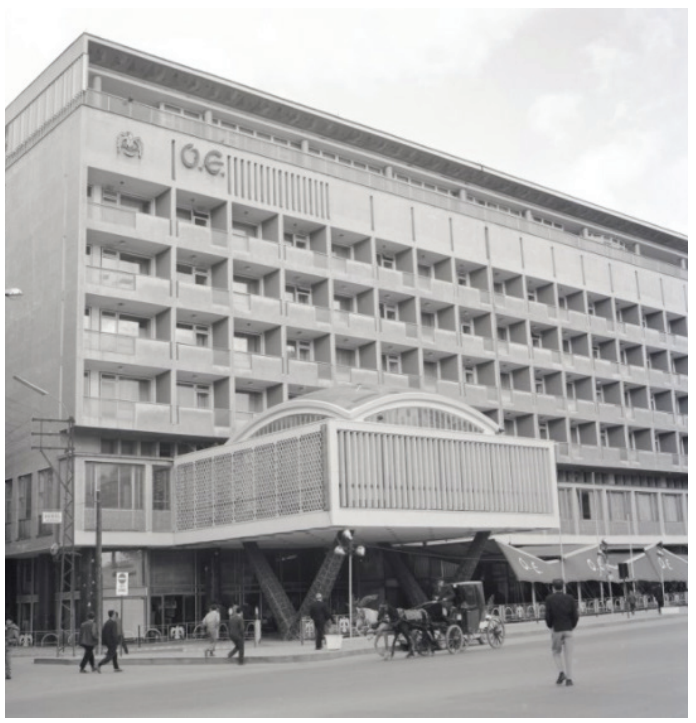

F.13. Scenes showing the V columns in the entrance block and the façade of Eskişehir Porsuk Hotel, 1958 (SALT Research, Gültekin Çizgen Archive)

\section{The Grand Efes Hotel}

After the successful operation of the Istanbul Hilton Hotel, the Pension Fund decided to build a hotel in Izmir. The project started in the old fair area near Cumhuriyet Square, one of the most central areas of İzmir. ${ }^{65}$ (Fig.14)

65 Ahmet Erdem Tozoğlu, Grand Hotels in Major Cities of Turkey, 1950-1980: An Evaluation of Modern Arc- 


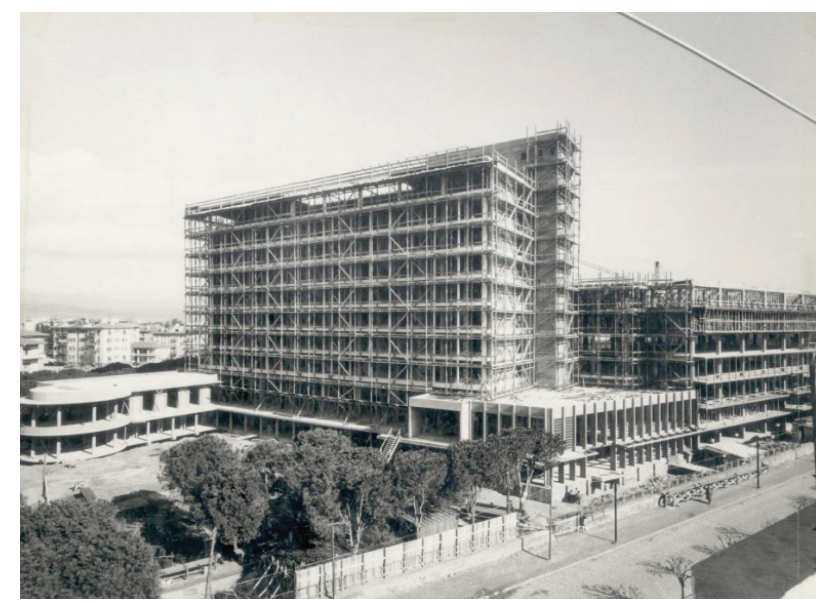

F.14. The Grand Efes Hotel's construction (Kenan Kurtkaya Archive)

The Grand Efes Hotel was developed in the 1950s to address the lack of a hotel and social venue in the city. Due to the limited municipality budget, Mayor of İzmir applied to the Pension Fund, to build a city club and hotel. The land was procured by the municipality, in the former fair area. The construction company, German firm Dyckerhoff and Windman undertook the construction and management on a basis of cost-plus profit. ${ }^{66}$ (Fig. 15)

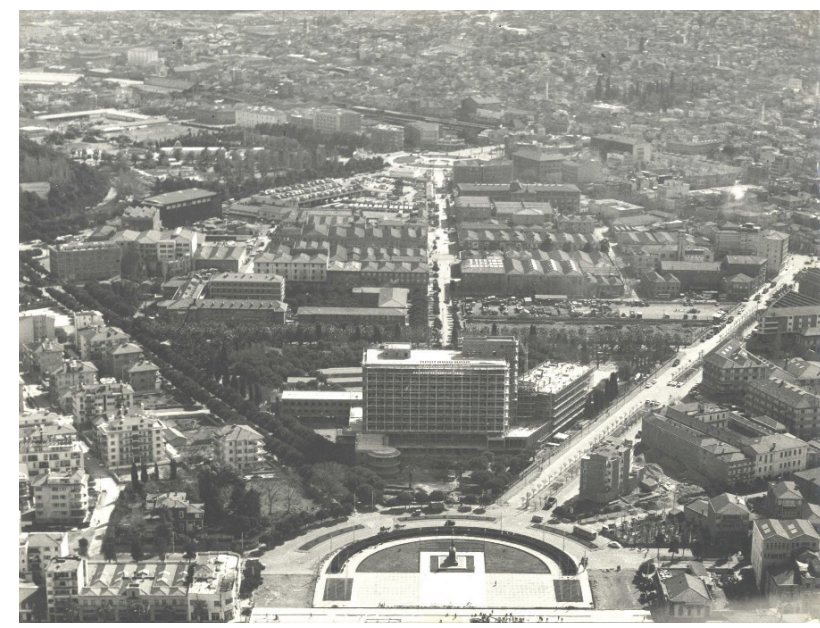

F.15. The Grand Efes Hotel's construction (Kenan Kurtkaya Archive)

hitecture and Tourism, Middle East Technical University, Graduate School of Social Sciences, Unpublished Master's Thesis, Ankara 2007, p.75.

66 Mehmet Özdemir, "Türk Turizminin Temel Taşlarından: Emekli Sandığı Otelleri” Anatolia: Turizm Araştırmaları Dergisi, 24 (2), Ankara 2013, pp. 266-275. 
To build the hotel, setting up a trade firm inside the Pension Fund became essential. For this, the fund approached the Dyckerhoff and Windmann company, and Emek Construction Company became a corporation belonging to the Pension Fund (49\%), Dyckerhoff and Windmann (49\%), Ankara Real Estate Management. Co, and Dr. Raif Gürün, Tutum Bank. Emek Construction Co. soon became involved in the construction of The Grand Efes Hotel (1958), Grand Tarabya Hotel (1958), the annex building of the Hilton Hotel (1959) and the base construction of Grand Ankara Hotel (1959). The technical knowledge was provided by the German firm meanwhile architects and engineers were recruited locally. ${ }^{67}$

Paul Bonatz was the main architect of the project, but after his death in 1957, Fatin Uran took over. ${ }^{68}$ Due to the foreign exchange shortage in 1957, the required financial aid of 200 million francs was borrowed from Belgium. Dykerhoff and Windmann Company won the hotel construction contract, and started on September 16, 1957. The hotel, due to be finished in 1960 with an expenditure of 10.9 million liras, was not completed until December 30,1963, and cost eight times the original estimate - 97.6 million liras. For this reason, the lease signed in 1955 with Hotel Continental was canceled due to the excessive cost and since no other company was available, Emek Construction Company took over the management. ${ }^{69}$

According to Arkitekt journal, the hotel covered an area of $36.000 \mathrm{~m}^{2}$. The accommodation consisted of 326 rooms with 495 beds. 22 were 2-room apartments, and 2 were 3-bed king-size suites with a living room, dining room and office. There was a 200-person restaurant, a rooftop restaurant, and a snack bar. For international conferences, there was a hall for 400, a night club for 200, an oriental Room for 50, Efe bar and roof bars, as well as various private lounges, souvenir shops on the ground floor and a swimming pool..$^{70}$

The Grand Efes Hotel was considered as the only Bonatz building in the international functionalist style. It was very similar to the Hilton Hotel with its architectural language consisting of a multi-storey rectangular prism. ${ }^{71}$ However, Kortan as cited in Tozoğlu states that the popularity of rational architecture of the 1950s began to fade towards the 60s. In the Grand Efes Hotel, it could be seen that the masses were distributed to different units with different heights, rather than collected in a single volume. The main and secondary bedrooms were the highest masses, while the entrance and the ball room had only double storeys. The building was no longer

67 A. E. Tozoğlu, op.cit., pp.80-81.

68 “Büyük Efes Oteli”, Arkitekt, 318, 1965, p. 40.

69 M. Özdemir, op.cit., 2013, p.272.

70 “Büyük Efes Oteli”, op.cit., pp. 5-13, 40-43.

71 Aslı Nevin Can Bilge, Paul Bonatz's Turkey years, İstanbul Technical University, Graduate School of Science, Engineering and Technology, Unpublished Master's Thesis, İstanbul 2017, p.258. 
limited to 90 degree angles. Grand Efes Hotel in this respect portrayed a different understanding from the Hilton Hotel. Thus, it was better adapted to the environment and closer to the human scale. New materials and technologies were also used in this hotel..$^{72}$ The differences from the Hilton Hotel was the use of different volumes for different functions, their separation in height and size, and their spatial variety. ${ }^{73}$

\section{The Grand Tarabya Hotel}

The Grand Tarabya Hotel was built on the site of the Konak Hotel (historical Tokatlyyan Hotel), which was destroyed by fire in $1954 .{ }^{74}$ When the new hotel's owners İbrahim Gültan and Paçitakis could not complete the building due to financial reasons, the unfinished hotel was purchased by the Pension Fund for 1.058.265 liras, and the remaining construction work and the management of the hotel was given to Emek Construction and Management Company. The building was originally planned to be finished in year 1961, but the construction took 7 years, until 30 November, 1965, increasing the cost from the original estimate of 19.2 million liras to 70.9 million liras. The hotel opened its doors on the first of April, 1966, the management was turned over to the Italian company SEAT. ${ }^{75}$

The Grand Tarabya Hotel, was located in a total of $11.441 \mathrm{~m}^{2}$ of land. It had 224 double rooms, 35 suites, 2 king suites, with a total 261 rooms and 522 beds. It had a 300 staff kitchen, a restaurant with a capacity of 4000 , a banquet hall with a capacity of 200, a sauna, a tennis court, indoor and outdoor swimming pools. ${ }^{76}$ According to the newspaper Milliyet in 1966, the furniture and building materials were brought from abroad, and the fixed and movable wooden furniture were made in the Technical Schools for Boys in Sultanahmet and Ankara. Each room had an ensuite bathroom and a telephone. ${ }^{77}$

Kortan states that the architectural language followed the Rational-International approach. It had a "Curvilinear Plasticity" similar to Le Corbusier's applications in South America, with a curved form parallel to the shore line (Fig.16). Considering the surroundings, Grand Tarabya Hotel was unique to its region. The area around the Bosphorus had a regional and traditional architectural character with a high sensitivity to its nature, geography and the human scale. However, the Grand Tarabya Hotel, due to its size was not compatible with the location. Ocean side hotels in

72 Enis Kortan, Türkiye'de Mimarlık Hareketleri ve Eleştirisi (1960-1970), Ankara 1973, as cited in Tozoğlu, 2007, p.87.

73 A. E. Tozoğlu, op.cit., p.93.

74 Burcu Karabaş, “Emek Otelleri’nin Hazin Öyküsü”, 2008, Retrieved 28.05.2019 from http://v3.arkitera. com/h36932-emek-otellerinin-hazin-oykusu.html.

75 Özdemir, op.cit., 2013, p.272.

76 Özdemir, op.cit., 2013.

77 Orhan Peksayar, “262 Odalı Tarabya Oteli 4 Nisan Günü Açılıyor”, Milliyet, 28 March 1966. 
America were on a scale to compete with the ocean, but the Bosphorus had its own distinct character with an urban pattern respecting the environment. Before the Grand Tarabya Hotel the silhouette of the Bosphorus was preserved intact and its natural beauty was not damaged, but the hotel's massive volume was incompatible with the surrounding area. The result was a large wall that damaged the land-sea connection, and created a situation which coastal hotels should avoid. ${ }^{78}$

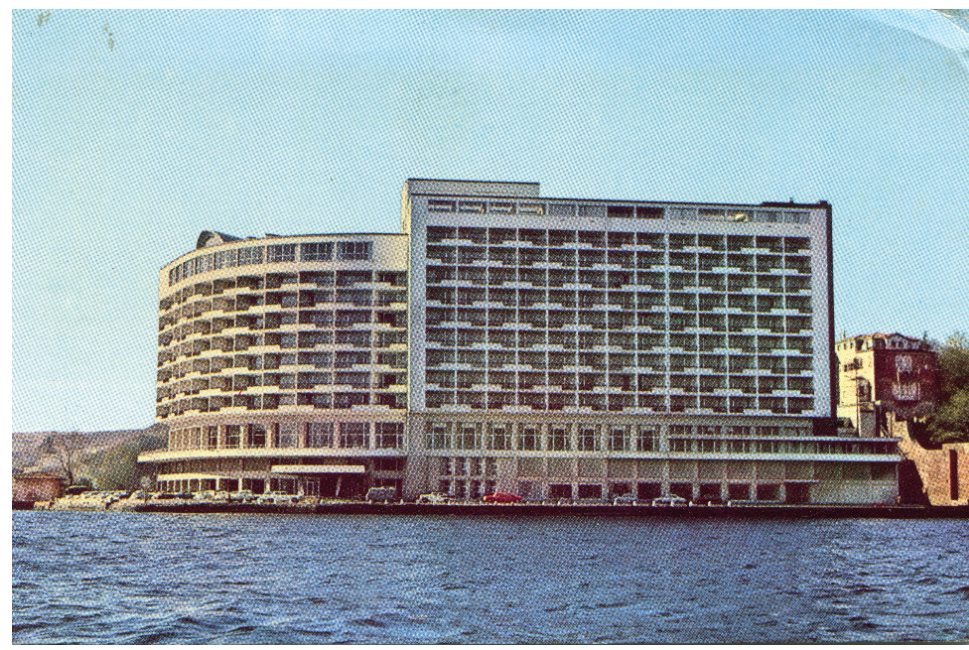

F.16. The Grand Tarabya Hotel (Atatürk Library Digital Archive, Krt_024551)

\section{Conclusion}

The 1950s was a period when Turkey was taking its first steps towards modern tourism. The opening of the İstanbul Hilton Hotel was in that sense a turning point. Since it was the first modern hotel, it dominated the discussions in tourism and popular journals of the period. Some hotels of this period followed the International Style after the Hilton Hotel, so closely that they were even called "Small Hilton", as examplified in this study, showing close formations of the building character. It should be noted that, even though they were not analysed in this paper, a vast amount of buildings were influenced by the Hilton Hotel in the mid-century. As the architect of another hotel of the period (Balin Hotel, 1953), Kadri Kalaycioğlu states, "The formation of the Hilton in front of us induced us to look for hotels in this sense, to see how hotels in the world are built. It directed our research, we were looking at such similar hotels". ${ }^{79}$

The process that emerged with the Hilton Hotel involved not only architectural features, but also the actors and the understandings that shaped other hotels. In the

78 Kortan, op.cit., 1971, p.54.

79 Kadri Kalaycioğlu, Personal Interview, Ankara 2018. 
1950 s, the state was the first to promote tourism, and many laws and incentives were introduced in these years. The concept of a modern hotel was unfamiliar until the country welcomed foreign companies, architects and engineering firms, such as the Hilton Hotel's contractor company Dyckerhoff and Windmann. This company also built Grand Efes and Grand Tarabya Hotels in collaboration with the Pension Fund. The Pension Fund also constructed Eskişehir Porsuk Hotel. The ambition to build with local revenue and Turkish architects was revealed with the Çınar Hotel as one of the first grand hotels constructed totally with Turkish capital and local expertise. As well as these state funded hotels, the Çınar Hotel, as a family enterprise, was contracted to the same German firm, Dyckerhoff and Windmann, underlying the dominance of foreign companies in the making of these hotels. It is here important to state that, state funded or family enterprise hotels as in the example of the Çinar Hotel, not only shared the architectural language but also common actors in their making.

It is seen that the buildings examined in this study were designed in a similar architectural language in the International Style that shaped the Hilton Hotel. Manifested in these buildings are the elevated rectangular prismatic block, glazed entrance floor, the use of the terrace, and the language created by the grid façade with balconies. These examples contain different levels of spatial elements such as terrace bars, restaurants, American bars, large landscaped areas with swimming pools. As Tekin and Akpinar state, the International Style formula was repeated on new buildings, and the grid of the reinforced concrete frame became prevalent not only in Istanbul, but nationwide. ${ }^{80}$

The mentioned hotels all share the main principles with the Hilton Hotel, but differentiations should be noted. The Grand Tarabya Hotel gained a plasticity due to the form of land. The Büyükada Anadolu Club Hotel was an example of a local interpretation within the same language, but using traditional elements and local habits associated with the Turkish traditional house. Eskişehir Porsuk Hotel differed in terms of the entrance with the elevated volume carried by V columns. The Grand Efes Hotel showed initial signs of breaking the rational attitude introducing the concept of breaking the volumes in different scales, and adapting to the environment with angular forms, which was beginning to emerge towards the 1960s.

Here it should be noted that this period between 1950-1960 was a time when Turkish architects applied modern architecture, which they learned through their own interpretations, inspired by western sources. ${ }^{81}$ According to Tanyeli, due to the fact that the conditions and technologies of the day were not developed, the existing details were

80 İlke Tekin, İpek Akpınar, "Betonarmenin Anonimleşmesi Türkiye'de İkinci Dünya Savaşı Sonrası Yapılı Çevrenin İnşaası", Mimarlık, 377, Ankara 2014, pp.70-74.

81 İlker Fatih Özorhon, Türkan Uluslu Uraz, “1950-60 Arası Türkiye Mimarlı̆̆ı'nda Özgünlük Arayışları”, İTÜ Dergisi/a Mimarlık, Planlama, Tasarım, 8 (2), İstanbul 2009, pp. 89-100. 
interpreted within the possibilities, but this driving force also caused the development of building methods. ${ }^{82}$ According to Tekeli as cited in Özorhon and Uluslu Uraz "Form follows function was a clear and honest formula....exclusion of the ornament and the revelation of the structure... We searched for originality inside this doctrine.. the search for an identity maybe was not widespread but there was the quest to use the availability of circumstances and not to adapt to the environment but to belong to it". ${ }^{83}$

The great influence of the Hilton Hotel, and American modern architecture generally, was visible in these examples. However, among these buildings, the Hilton had a unique status as the first modern hotel building, which was the leading example in a world characterized by developing tourism and architecture. These efforts could be seen as aimed at realizing ambitions to keep up with the rest of the world, within the conditions of the day. Bozdoğan also adds that, what is termed as "Hiltonism" (Hiltonculuk) was in a way a rational solution to hotel and apartment buildings that require repetition of spaces in building programs. These buildings signify how modern architecture was internalized and adapted to the country's conditions. ${ }^{84}$ Tanyeli asserts that imitation as a concept encourages the production of the original in the newly encountered geographies, which is a natural course in development. The problem here is that the boundaries between a copy and an original are strictly divided, which makes it hard to trace the authenticity, although a closer analysis reveales the originality of the work. Thus, the architectural production of the 1950s, emerged as the result of the tendency of the period and Turkey following an international approach. ${ }^{85} \mathrm{Uz}$ expresses that architecture is built upon expanding previous knowledge so the "original" and the "copy" issue in architecture is senseless. Therefore, it is necessary to look at all processes and concepts that make up the result, not the end product. In this context, the term "originalcopy" comes out, which are products that show resemblences to another, however produced within a deep understanding and "conscious differentiation" that portray their own unique attributes ${ }^{86}$ In this sense, tourism architecture in the 1950s of Turkey should be considered as examples showing the reflection of an understanding of the world which developed in parallel.

All of the mentioned hotels are still standing, although some have undergone alterations and renovations in recent years. As Bozdoğan states, the Hilton has undergone many alterations, moving it away from the initial design, whereas Anadolu

82 Uğur Tanyeli, 1950'lerden Bu Yana Mimari Paradigmaların Değişimi ve 'Reel'Mimarlık. In Y. Sey (Ed.), 75 Yılda Değişen Kent ve Mimarlık, İstanbul: Turkish History Association Press, 1998 Ankara, pp. 235-254.

83 D. Tekeli, Personal Interview, 2006, as cited in İ.F. Özorhon, T. Uluslu Uraz, op.cit., p.95.

84 Sibel Bozdoğan, Hiltonculuk, In T. Elvan Altan, Sevil Enginsoy Ekinci (Eds.), İnci Aslanoğlu için bir Mimarlık Tarihi Dizimi, Ankara 2019, p.2.

85 Uğur Tanyeli. "Biz hep mi taklit ederiz?" Arredamento Mimarlık, 6, İstanbul 2001, pp. 6-7.

86 Funda Uz, "Hukukçular Sitesi as the Stage of Everyday Life", In Pelin Derviş (Ed.). Places of Memory, (curator: Murat Tabanlığlu), İstanbul, Venice 2014. 
Club Building is aging in poor condition ${ }^{87}$, but still serves as a hotel run by Anadolu Club, a non-governmental organization. ${ }^{88}$ The main block of the Çinar Hotel, despite many interior renovations, and annex building added in the 1970s, preserves its original character. The hotel is still run by the third generation of the founding Ercan family. ${ }^{89}$ Efes Hotel was privatized in 2002 and management was transferred to the Swissotel chain. After a remodeling phase between years 2006-2008, it opened under the new name Swissotel Grand Efes İzmir and continues to operate. The interior was remodeled and there was an addition of rooms. ${ }^{90}$ Porsuk Hotel serves as Officer's Club, and has had major alterations to the façade, as the balconies were incorporated into the rooms. It is here important to say that these hotels also functioned as well-established landmarks in the cities they served. For this reason, further research should integrate the study of these hotels into a wider discussion on their social value in everyday life, and the wide-ranging effects of tourism on social life in the mid-century.

We would like to express our sincere gratitude to Emre Gönlügür, Gökçeçiçek Savaşır, Müge Cengizkan and Simon Mumford.

Grant Support: The author received no financial support for this work.

\section{References/Kaynakça}

ADALET, Begüm, Hotels and Highways: The Construction of Modernization Theory in Cold War Turkey, Stanford, California 2018.

AKCAN, Esra; BOZDOĞAN, Sibel, Turkey: Modern Architectures in History, Glasgow 2013.

AKCAN, Esra, Americanization and Anxiety: Istanbul Hilton Hotel by SOM and Eldem. In S. Bozdoğan, Ü. B. Copur (Eds.) Oriental Occidental: Geography, Identity, Space. Paper presented at ACSA International Conference, 2001.

AKCAN, Esra, “Amerikanlaşma ve Endişe; İstanbul Hilton Oteli.”, Arredamento Mimarlık, İstanbul 2001, pp.112-119.

ALTAN, T. Elvan, "Modern Tourism Architecture in 'A Country with Every Touristic Feature': An Overview of Hotels, Holiday Villages and Houses in Post-War Turkey". In Alina Serban, Kalliopi Dimou, and Sorin Istudor (Eds.) Enchanting Views: Romanian Black Sea Tourism Planning and Architecture of the 1960s and 70s. Bucharest 2015, pp. 236-249.

“Anadolu Kulübü Binası”, Arkitekt, 295, 1959, pp. 45-52.

ASASOĞLU, Ali, Çağdaş Türk Mimarlığı Kimlik Arayışı Sürecinde Eklektik Eğilimler, Karadeniz Technical University, Institute of Natural Sciences, Master's Thesis, Trabzon 1988.

ATAY, Ümit, “Otel Davası Tamamen Halledilemiyor”, Turing, 1956 January, p.19.

87 S. Bozdoğan, op. cit., 2016, p. 23.

88 http://www.anadolukulubu.com/tr/

89 Esen Çetingil, Personal Interview, İstanbul 2018.

90 Zeynep Tuna Ultav, Gökçeçiçek Savaşır, “The Erasure of History in the Remodeling of the Grand Efes Hotel in İzmir", Interiors, 3(3), 2012, pp. 181-202. 
BAYRAKTAR, Erdoğan, “Eskişehir Hilton'u”, Milliyet, 1959 October 01. Retrieved 09.07.2019 from Milliyet Newspaper Online Archive.

BOZDOĞAN, Sibel, Hiltonculuk. In T. Elvan Altan, Sevil Enginsoy Ekinci (Eds.), İnci Aslanoğlu için bir Mimarlık Tarihi Dizimi, Ankara 2019.

BOZDOĞAN, Sibel, Turkey's Postwar Modernism: A Retrospective Overview of Architecture, Urbanism and Politics in the 1950s. In M. Gürel (Ed.) Mid-Century Modernism in Turkey: Architecture across Cultures in the 1950s and 1960s, New York and London 2016.

“Büyük Efes Oteli", Arkitekt, 318, 1965.

CAN BİLGE, Aslı Nevin, Paul Bonatz's Turkey Years, İstanbul Technical University, Graduate School of Science, Engineering and Technology, Unpublished Master's Thesis, İstanbul 2017.

CONKER, Sibel, İstanbul'daki Kent Otellerinin Mekan Dizim Yöntemiyle Analizi, Yıldız Technical University, Graduate School of Natural and Applied Sciences, Unpublished Master's Thesis, İstanbul 2009.

ÇETINGIL, Esen, Personal Interview, İstanbul 2018.

“Çınar Oteli”, Arkitekt, 297, April 1959, pp.132-140.

DEMIREL ETLİ, Pınar; KURT Özlem, Eskişehir Porsuk Oteli, Docomomo_Türkiye Mimarlığında Modernizmin Yerel Açılımları, 31 October-2 December 2014 Erzurum.

DURUKAL, Hüsnü Sadık, “Otelcilik Endüstrisi ve Turizm”, Turing, March 1956, pp.3-4.

ELDEM, Sedad Hakk1, “Elli Yıllık Cumhuriyet Mimarlığı”, Mimarlık, Ankara 1973.

“Eskişehir Porsuk Oteli Açılıyor”, Milliyet, 21 October 1959.

EVCINN, Erol, "Basın-Yayın Ve Turizm Bakanlığı Döneminde Turistik Tanıtım ve Propaganda (1957-1963)". Atatürk Dergisi, 6 (2), Erzurum 2016, pp. 41-91.

“Fenerbahçe'de yapılacak olan otel”, Hayat, İstanbul 1 March 1957.

"Finally the Hilton Hotel, or a Hotel", SALT Research, Rahmi M. Koç Archive, File No: D.156.

GÖNLÜGÜR, Emre, Personal Interview, İzmir 2019.

GÖNLÜGÜR, Emre, American Architecture and the Promise of Modernization in Postwar Turkey, University of Toronto, Graduate Department of Art, Doctoral Dissertation, Toronto 2014.

GÖRKEY, Aykut, "Hilton ayarında 6 otel daha yapılacak", Turing, 1957 December, pp.12-13.

GÜLERSOY, Çelik, "Hotel d'Angleterre”, Cumhuriyet, İstanbul 31 August 1989. Retrieved from Taha Toros Online Archive, http:/earsiv.sehir.edu.tr:8080/xmlui/handle/11498/4234.

GÜRSOY, Özdemir, “17 Katlı Otel”, Milliyet, 5 July 1958, Retrieved 28.05.2019 from http://gazetearsivi.milliyet.com.tr.

“Hilton'un Benzeri”, Milliyet, 11 June 1955, Retrieved 28.05. 2019 http://gazetearsivi.milliyet. com.tr.

HITCHCOCK, Henry Russell; JOHNSON Philip, The International Style: Architecture Since 1922, New York 1932.

İstanbul Hilton Otel, Krt_02657, Retrieved from İstanbul Atatürk Library Digital Archive.

“İstanbul bir otel kazandı”, Hayat, 29 August 1958.

“İstanbul'un Otel Davası”, 1945, Retrieved 28.05.2019 from Taha Toros Online Archive, http:// earsiv.sehir.edu.tr:8080/xmlui/handle/11498/2422. 
KAÇEL, Ela, "This is Not an American House: Good Sense Modernism in 1950s Turkey." In Duanfang Lu (Ed.) Third World Modernism: Architecture, Development and Identity, London 2011, pp.165-185.

KAÇEL, Ela, "Hiltonculuk and Beyond: The Dialectics of Intellectualism in Postwar Turkey." Candide: Journal for Architectural Knowledge, N. 3, Aachen 2010, pp. 9-35.

KALAYCIOĞLU, Kadri, Personal Interview, Ankara 2018.

KARABAŞ, Burcu, “Emek Otelleri’nin Hazin Öyküsü”, 2008, Retrieved 28.05.2019 from http:// v3.arkitera.com/h36932-emek-otellerinin-hazin-oykusu.html.

KOCA Güler; KARASÖZEN Rana, “1945-1960 Dönemi Eskişehir Modern Kent Merkezinin Oluşumunda Öne Çıkan Yapılar”, Anadolu University Journal of Social Sciences, 10 (3), Eskişehir 2010, pp.191-211.

KORTAN, Enis, Türkiye'de Mimarlık Hareketleri ve Eleştirisi, 1950-1960: XX. Yüzyılın Başından 1950'ye kadar olan Sürede Modern Mimarlığın Dünya'daki ve Türkiye'deki Gelişmesiyle Birlikte, Ankara 1971.

KORTAN, Enis, Türkiye'de Mimarlık Hareketleri ve Eleştirisi (1960-1970), Ankara 1973.

KÜÇÜKERMAN, Gözen, Personal Interview, İstanbul 2018.

Ministry of Press, Broadcasting and Tourism, İstanbul [Brochure]. 1958 İstanbul. Retrieved from Atatürk Library Digital Archive, Muhsin Ertuğrul Collection.

NAYIR, Y. Nabi, “Otelsiz Şehir”, Yeni Sabah, 8 September 1941, Retrieved 28.05.2019 from Taha Toros Online Archive, http://earsiv.sehir.edu.tr:8080/xmlui/handle/11498/2422.

ORGUN, Vahid, “Turizm ve Organizasyon”, Turizm Alemi, 2, April 1954.

ÖZDEMIR, Mehmet, "Türk Turizminin Temel Taşlarından: Emekli Sandığı Otelleri” Anatolia: Turizm Araştırmaları Dergisi, 24 (2), Ankara 2013, pp. 266-275.

ÖZORHON, İlker Fatih, The Issue of Originality in Architecture: Turkish Modernity in the Period of 1950-60, İstanbul Technical University, Graduate School of Science, Engineering and Technology, Doctoral Dissertation, İstanbul 2008.

ÖZORHON, İ. F; ULUSLU URAZ, T, “1950-60 Arası Türkiye Mimarlığı’nda Özgünlük Arayışları”, İTÜ Dergisi/a Mimarlık, Planlama, Tasarım, 8 (2), İstanbul 2009, pp. 89-100.

PEKSAYAR, Orhan, “262 Odalı Tarabya Oteli 4 Nisan Günü Açılıyor”, Milliyet, 28 March 1966.

SALT Research, Fazıl Saffet Aysu Archive.

SALT Research, Güntekin Çizgen Archive.

SAYAR BAŞARAN, Sevgi. (2007, March 9). "Çınar Hotels targets the young”. Hürriyet Daily News, Retrieved http://web.archive.org/web/20160304205813/http://www.hurriyetdailynews.com/cinar-hotel-targets-the young.aspx? pageID $=438 \& n=$ cinar-hotel-targets-theyoung-2007-09-03.

SEZGIN, Mukadder, Personal Interview. Ankara 2018.

TANYELİ, Uğur, 1950'lerden bu yana mimari paradigmaların değişimi ve 'reel'mimarlık. In Y. Sey (Ed.), 75 Yılda Değişen Kent ve Mimarlık, Ankara1998, pp. 235-254.

TANYELİ, Uğur, “Biz hep mi taklit ederiz?” Arredamento Mimarlık, 6, İstanbul 2001, pp. 6-7.

TEKİN, İlke; AKPINAR, İpek, “Betonarmenin Anonimleşmesi Türkiye’de İkinci Dünya Savaş1 Sonrası Yapılı Çevrenin İnşaası”, Mimarlık, Ankara 2014, 377, pp.70-74.

The Grand Tarabya Hotel, Krt_024551, Retrieved from İstanbul Atatürk Library Digital Archive. 
TİL, Enis Tahsin, "Yeni Oteller”, Turing, September 1955, p.15.

TUNA ULTAV, Zeynep; SAVAŞIR, Gökçeçiçek, 50 Yılın Ardından Türkiye’nin İlk Otel Motel Zinciri TUSAN, İzmir 2016.

TUNA ULTAV, Zeynep; SAVAŞIR, Gökçeçiçek, "The Erasure of History in the Remodeling of the Grand Efes Hotel in İzmir”. Interiors, 3(3), 2012, pp. 181-202.

“Turistik Otel”, Arkitekt, 1952-03, pp.56-63.

TOZOĞLU, Ahmet Erdem, Grand Hotels in Major Cities of Turkey, 1950-1980: An Evaluation of Modern Architecture and Tourism, Middle East Technical University, Graduate School of Social Sciences, Unpublished Master's Thesis, Ankara 2007.

UZ, Funda, "Hukukçular Sitesi as the Stage of Everyday Life", In Pelin Derviş (Ed.). Places of Memory (curator: Murat Tabanlıoğlu), İstanbul, Venice 2014.

ÜNVER, Rüçhan, "Haftaya Açılıyor”, Milliyet, 07 July 1958, p.3.

VANLI, Şevki, Mimariden Konuşmak: Bilinmek İstenmeyen 20. Yüzyıl Türk Mimarlığı, Eleştirel Bakış (V1), Ankara 2006.

VANLI, Şevki, “Hiltonculuk”, Kim, 29 November 1958, pp. 31-32.

WHARTON, Annabel Jane, Building the Cold War: Hilton International Hotels and Modern Architecture, U.S.A 2001.

YILDIZ, Zafer, “Turizmin Sektörünün Gelişimi ve İstihdam Üzerindeki Etkisi.” Süleyman Demirel University, The Journal of Visionary, 3 (5), Isparta 2011, pp. 54-71.

ZAT, Vefa, Eski İstanbul Otelleri: İstanbul Hilton 50 yaşında, İstanbul 2005.

http://www.anadolukulubu.com/tr/ 